\title{
Intervention Strategies for Controlling Poultry Coccidiosis: Current Knowledge
}

\author{
Wafaa A. Abd El-Ghany \\ Poultry Diseases Department, Faculty of Veterinary Medicine, Cairo University, Giza, Egypt \\ *Corresponding author's Email: wafaa.ghany@yahoo.com, ORCID: 0000-0003-1686-3831
}

Received: 03 October 2021

Accepted: 20 November 2021

\begin{abstract}
Poultry coccidiosis is considered one of the most important continuous threats that frustrates the poultry industry around the world and causes serious adverse effects on poultry productivity. Accordingly, this article comprehensively reviewed the recent control strategies that are applied against such disease regarding medication, vaccination, and application of some natural products. The causative agent of coccidiosis is a protozoon parasite of the genus Eimeria. This parasite is characterized by the host, different parts of the intestines, and immune specificity. Chicken is the most susceptible host to intestinal infections with Eimeria species. Diarrhea, loss of profitability, and intestinal lesions are the most characteristic clinical picture of Eimeria infection. Prevention and control of such infections remain a great problem. The application of hygienic measures is still the gold standard for the prevention of avian coccidiosis. Anticoccidials medication either in the feed or water can effectively reduce Eimeria infection, however, the development of drug resistance to the commonly used anticoccidial drugs is incessant. Live nonattenuated and attenuated as well as recombinant and sub-unit vaccines were developed with some limitations. Therefore, using some natural alternatives, such as probiotics, prebiotics, and phytobiotics have emerged as anticoccidial compounds.
\end{abstract}

Keywords: Chicken, Eimeria, Intestine, Natural products, Medication, Vaccination

\section{INTRODUCTION}

The poultry industry is regarded as one of the most important growing sectors of agriculture that contributes to the world's nutrition (Mottet and Tempio, 2017). However, this industry is exposed to many serious diseases that hamper and threaten the productivity of poultry among which coccidiosis disease can be named (Blake and Tomley, 2014).

Poultry coccidiosis is considered a devastating and problematic parasitic intestinal disease that causes severe economic losses in the poultry industry worldwide. Financial losses were estimated at 3 billion dollars annually, mainly due to the costs of medications and vaccinations, mortalities, and decreasing profitability in coccidiosis-affected birds (Noack et al., 2019). The life cycle of this parasite is complex and consists of an exogenous phase in the environment and an endogenous phase in the intestine of the birds. Diseased birds with coccidiosis showed mortalities, decreased feed efficiencies, growth retardation, and suppression of cellmediated and humoral immunity (Chapman et al., 2013).
In addition, coccidiosis is usually associated with a transient drop in egg production in layer chickens and increased susceptibility to some other disease outbreaks, such as necrotic enteritis in broiler chickens (Noack et al., 2019). Avian coccidiosis is an enteric infection that is caused by a protozoon parasite of the phylum Apicomplexa and genus Eimeria. Most domestic avian species, especially younger ones, can be infected with specific Eimeria species. Chickens are highly susceptible to seven species of Eimeria that vary in their pathogenicity and replication site of the intestine (Chapman, 2014). Different developmental stages of Eimeria life cycle penetrate the intestinal cells resulting in detrimental damage, inflammation, and hemorrhages (Lillehoj and Trout, 1996).

Owing to the drastic adverse effect of poultry coccidiosis on the global industry, different prophylactic and control measures have been deployed. Strict biosecurity and hygienic measures accompanied by using preventive medicaments are the first bedrock strategies against the infection (Godwin and Morgan, 2015). Using prophylactic and therapeutic anticoccidial drugs is the 
most common and traditional intervention for the prevention and control of avian coccidiosis (Snyder et al., 2021). Due to the continuous development of drug resistance and bans on using anticoccidial drugs, it becomes urgent to search for non-conventional and new alternatives to control such infection searching for new alternatives and nonconventional approaches to control this costly avian disease becomes an urgent demand (Adhikari et al., 2020). These approaches may include applying live virulent and attenuated as well as recombinant Eimeria species vaccines (Soutter et al., 2020; Snyder et al., 2021). Vaccination can be alternated with anticoccidial drugs in the feed within rotation programs and in combination with biosecurity measures. The utilization of some natural products, such as probiotics, prebiotics, and natural herbs with their extracts is also another safe and effective alternative for coccidiosis control (Awais et al., 2019; Gordillo Jaramillo et al., 2021; Tsiouris et al., 2021).

This review summarized the epizootiology and clinical picture of poultry coccidiosis, and comprehensively showed the recent control strategies that are applied against such disease regarding medication, vaccination, and application of some natural products.

\section{Epizootiology and clinical picture}

More than 1000 Eimeria species have been found to infect different hosts, including animals and birds (chickens, turkeys, ducks, geese, and pigeons, Blake, 2015). Seven Eimeria species, including Eimeria (E) tenella, E. necatrix, E. brunetti, E. maxima, E. acervulina, E. mitis, and E. praecox, have been recorded in chickens. Each species of Eimeria has a specific developmental site in each part of the intestine (upper, middle, and lower). Many Eimeria species can infect poultry without crossimmunity between them. All ages of chickens are susceptible to coccidial infection; however, the infection mostly begins at a younger age (older than one week) as the immune system is immature. Older birds are relatively resistant as a result of prior exposure to coccidiosis.

Infection with Eimeria species usually occurs through the oral ingestion of contaminated food, water, or litter that contains large quantities of infective sporulated oocysts (Gharekhani et al., 2014). Mechanical transmission of Eimeria oocysts from one house to another through wild birds, rodents, insects as well as contaminated boots and clothes of personnel, equipment, or dust was recorded (Belli et al., 2006).

Infected birds voided in their droppings a large number of non-sporulated oocysts. These oocysts require certain bad housing and management system with special environmental conditions, such as warm temperature (25$30^{\circ} \mathrm{C}$ ), high humidity (40-80\%), and aeration (oxygen) for sporulation (Mohammed and Sunday, 2015). Accordingly, coccidiosis is more rampant in the intensive deep litter system than other types of housings such as cages or battery systems. Eimeria oocysts have thick walls of lipid and protein, thus they are stable and resist mechanical and chemical destructive agents, harsh heat and cold as well as proteolytic degradation (Belli et al., 2006; Mai et al., 2009). It has been shown that sporulated oocysts can persist in the environment for more than 2 months, but non-sporulated ones can persist for 7 months in the caecum of the host (Quiroz-Castan eda and Danta'nGonza'lez, 2015). Temperatures above $35^{\circ} \mathrm{C}$ and below $0^{\circ} \mathrm{C}$ can be lethal for oocysts. It is so difficult to decontaminate previously oocysts-contaminated poultry houses.

Eimeria species have a self-limiting life cycle characterized by host and tissue specificity. This life cycle is complex and embraces sporogony, schizogony (merogony), and gametogony. After ingestion of tetrasporocystic-disporozoites sporulated oocysts, some physical and chemical agents are secreted in the proventriculus and gizzard that help release mature infectious sporozoites form sporocysts. Consequently, the sporozoites penetrate the intestinal epithelial cells using penetration proteins and form trophozoites and then schizonts during the schizogony (merogony) stage (Blake and Tomley, 2014). Merozoites enter the epithelium and continue this merogony stage 2-3 times for increasing the cell number of merozoites at the asexual stage of reproduction. Finally, merozoites are differentiated into male microgametes and female macrogametes sexually reproduced to form zygotes (non-sporulated oocysts) voided in the droppings of the infected birds. The complete life cycle of different Eimeria species may take about 4-7 days (Hammond, 1973).

The severity of the clinical picture of coccidiosis is dependent on the species of Eimeria, the number and pathogenicity of the ingested sporulated oocysts, the host's age and immunity along with the environmental management. Many species of Eimeria in chickens are of high pathogenicity, such as E. tenella, E. necatrix, E. brunetti, E. acervulina, and E. maxima, while E. praecox and E. mitis are of low pathogenicity (Jadhav et al., 2011). The small intestine and caecum are the target sites of Eimeria species that take 5-6 days incubation period till the appearance of signs. (Musa et al., 2010). Affected birds may show general signs of depression, huddling, and 
ruffling, reduced food intake, and watery-whitish or bloody diarrhea (Blake, 2015). Consequently, poor weight gain, dehydration, and death can occur. A sub-clinical form of coccidiosis is frequently observed without specific intestinal signs or lesions. It is often not detected but mostly results in poor feed conversion and reduced weight gain of the flock.

The inflammation or damage lesions caused by Eimeria species in different parts of the gut depend mainly on their degree of pathogenicity (Morris et al., 2007). These lesions include thickening of the intestinal wall, mucoid to bloody exudates, mucosal petechial to ecchymotic hemorrhages, necrosis, and hemorrhagic enteritis or typhlitis. Affected caecum may show the development of the caecal core. Secondary colonization by some bacteria, such as Clostridium perfringens (Helmbolt and Bryant, 1971), or Salmonella typhimurium (Baba et al., 1982), may be seen in the damaged intestines. Moreover, the severity of Histomonas meleagridis infection could be increased in case of coinfecion with $E$. tenella (Mcdougald and $\mathrm{Hu}, 2001$ ). Accordingly, intestinal coccidiosis is difficult to be differentiated from other similar lesions of some diseases, such as necrotic enteritis, ulcerative enteritis, salmonellosis, and histomoniasis (Hafez, 2008). A coccidiosis 'break' indicates immunosuppression due to concomitant infection with immunosuppressive viral diseases which interferes with the development of immunity and aggravates coccidial infection (Mcdougald et al., 1979).

\section{Applied control strategies}

Management and hygienic measures

Application of management and hygienic measures is crucial for successful prophylaxis or even treatment of coccidiosis especially when drug-resistance strains of Eimeria are predominated. The management protocol includes all parameters that can keep good litter quality, such as appropriate installation and management of watering systems, provision of adequate feeding space, maintaining suitable stocking density, and supplying adequate ventilation. Birds should be separated from the environment and from other mechanical carriers of Eimeria such as rodents and insects. Restriction of traffic between farms is essential. It has been shown that ammonia gas produced from ammonium salt and sodium hydroxide is active in destructing Eimeria oocysts. Liquid or vapor forms of 5\% ammonium hydroxide revealed high efficacy against $E$. tenella oocysts (Chroustova and Pinka, 1987). Disinfection with $37 \%$ formol and $12 \%$ sodium dodecylbenzene sulphonate or with calcium hydroxide and ammonium sulphate combinations are very efficient against Eimeria oocysts (Gumara es et al., 2007). Moreover, cresol compounds are also used as a good disinfectant against different stages of Eimria species (Daugschies et al., 2002).

However, it is believed that oocysts in the litter of birds are useful for the early establishment of immunity to avoid later outbreaks of coccidiosis (Allen and Fetterer, 2002). Therefore, cleaning and disinfection should be skipped under certain conditions to repopulate the litter with drug-sensitive Eimeria strains and to keep the survival of vaccine strains between vaccinated and nonvaccinated birds.

Reducing Eimeria infection of chickens can be achieved via reducing sporulation of oocysts in the environment, mainly through maintaining dry litter and keeping ventilation in houses (Etuk et al., 2004). Sanitary management of litter is a very important factor to control coccidial infection among consecutive flocks. In this regard, it is of utmost importance to completely remove contaminated litter after chicken marketing, and provide fresh and dry bedding before chick placement. However, different litter treatments reduce oocyst count and output. The used litter could be treated among flocks, and a small number of fresh shavings could be added (Coufal et al., 2006). Treatments including fermentation or addition of $800 \mathrm{~g} / \mathrm{m}^{2}$ calcium oxide to the litter efficiently reduced the count and sporulation of Eimeria oocysts (Beninca et al., 2021). In addition, poor management of litter can exacerbate coccidiosis, prevent the taking of a sufficient number of oocysts of the vaccines, and limit the cycling of oocysts (Attree et al., 2021). Managing litter moisture and house humidity are critical for sporulation of oocysts and eventually, the success of the vaccine through on-farm cycling (Williams, 2002).

\section{Medication}

The global mainstream agents used for controlling avian coccidiosis are anticoccidial drugs. Anticoccidials could be classified into synthetic or chemical compounds (such as sulphonamides, amprolium, amprolium ethopabate, nicarbazin, halofuginone, clopidol, robenidine, dinitolmide, pyridones, aprinocid, quinolone, methyl benzoquate, diclazuril, and toltrazuril) and polyether ionophorous compounds (ionophores; including narasin, lasalocid, bacitracin, maduramicin, semduramicin, virginiamycin, avilamycin, monensin, and salinomycin). They were effectively used in different combinations and concentrations for broiler and layer chickens as well as turkeys according to the manufacturer's instructions 
(Shivaramaiah et al., 2014). The withdrawal period of these compounds varies from one to five days (Hafez, 2008).

Anticoccidial drugs target different developmental stages of the protozoon, such as the sporozoites or merozoites. Few anticoccidials show equal efficiency against all species of Eimeria (Mcdougald, 2003). The ideal anticoccidial drug should mostly affect all the developmental stages of Eimeria species, do not disturb the host's immune response, and has no tissue residues. Besides, it should permit a small leakage of the protozoon to enable the host to build up a degree of immunity. However, anticoccidials prevent treated chickens from building up natural immunity and some are not completely efficient to destroy all the developmental stages of the protozoon. Consequently, Eimeria species quickly became resistant to the used drugs leading to frequent severe disease outbreaks.

\section{Synthetic anticoccidials}

Synthetic anticoccidials are effective and commonly used in the field. Early successful treatment of coccidiosis was achieved after using low concentrations of sulphaquinoxaline in the feed (Delaplane et al., 1947). Sulfonamides have efficient coccidioststic and coccidiocidal activities ( $\mathrm{Li}$ and $\mathrm{Bu}, 2014$ ). In the protozoa, sulfonamides are the competitive antagonist of paraaminobenzoic acid, a precursor of folic acid, which is an essential coenzyme for the synthesis of deoxyribonucleic acid (Harfoush et al., 2010). Moreover, sulfonamides proved effective antibacterial potency, so they prevent secondary bacterial infections which often occur after coccidiosis (Yegani and Korver, 2008). A major side effect of sulphonamides is their narrow safety margin, which leads to intoxications, especially after treatment of coccidiosis outbreaks.

Nicarbazin was introduced to the USA in 1955 and it was extensively used in broilers production (Chapman, 1994). It acts by inhibition of succinate-linked NAD reduction in mitochondria and transhydrogenase and accumulation of Ca2 ions (Dougherty, 1974). Accordingly, it inhibits the first and second generations of the schizont of the parasites. However, it is not used for layer chickens due to its adverse effects on the egg quantity and quality.

Amprolium also acts by competitive inhibition of thiamine uptake and completely blocks the absorption of thiamine. It is efficacious against the first generation of schizogony and the gametogony where the demand for thiamine is at its highest (James, 1980) allowing the development of immunity (Reid, 1975). Ethopabate is often used in combination with amprolium to improve efficacy. Some studies compared the efficacy of using sulfonamides and amprolium and the results proved that both medicaments were efficient against Eimeria infection with variable degrees (Khan et al., 2021). Ethopabate and sulphonamides affect the second generation of schizonts.

Quinolone group includes buquinolate, decoquinate, and nequinate (benzoquate). At very low concentrations, these drugs acted by inhibition of Eimeria respiration through blocking the electron transport in their mitochondria (Wang, 1975) and also stopping the development of sporozoites (Reid, 1973). Similarly, the pyridone group contains meticlorpindol compound which inhibits electron transport in mitochondria of the protozoon.

Toltrazuril, a triazinetrione derivative is used in drinking water as a prophylactic and therapeutic medicament. It affects all intracellular schizogony and gametogenic stages of all Eimeria species in chickens (Shivaramaiah et al., 2014). Toltrazuril interferes with the nucleus division and the mitochondrial activity, which are responsible for the respiratory metabolism of the protozoon (Noack et al., 2019). Moreover, it destructs the so-called wall-forming bodies in the macrogamete and consequently induces vacuolization in all intracellular developmental stages. It produces cidal changes in the plastid-like organelles at multiple levels without impairment of natural immunity development (Hackstein et al., 1995). It has been found that toltrazuril treatment of mice induced reduction of some respiratory enzymes, such as nicotinamide adenine dinucleotide oxidase, succinatecytochrome $\mathrm{C}$ reductase, succinate oxidase, and dihydroorotate-cytochrome $\mathrm{C}$ reductase (Harder and Haberkorn, 1989). Treatment of coccidiosis infected broiler chicks with toltrazuril induced improvement in feed intake, weight gain, and food conversion rate, besides reduction in oocyst number (Badrawy, 2012).

Diclazuril is also involved in the synthesis of nucleic acid and may affect the schizogony and gametogenic phase of the parasite (Verheyen et al., 1988). Moreover, the drug can affect the synthesis of the oocysts wall resulting in the formation of an abnormally thickened, incomplete oocyst wall as well as non-sporulated oocysts necrosis for some Eimeria species (Verheyen et al., 1989).

The exact mode of action of robenidine, a guanidine derivative, is not well known. But it can show inhibition of oxidative phosphorylation of mitochondria (Wong et al., 1972). Besides, a quinazolinone derivative, halofuginone, inhibits the first generation of the schizogony stage. 


\section{Ionophorous anticoccidials}

In the 1970s, monensin was the first ionophore coccidiostats introduced to the poultry field, and as reported, it inhibits Clostridium perfringens associated with necrotizing enteritis (Martel et al., 2004). Salinomycin also showed antibacterial effects against coliforms, Streptococci (George et al., 1982), and Salmonella typhimurium (Ford et al., 1981). Ionophores disrupt ion gradient across the parasite cell membrane. Resistance to ionophores develops very slowly with a tendency to increase the level of tolerance and they have some influences on the intestinal microbial populations (Dibner and Richards, 2005). Marginal to the poor effect of different ionophores on many Eimeria species was reported (Mathis, 1999). However, it has been found that the combination of antibiotics and ionophores is likely responsible for lower mortality in the medicated flocks (Thabet et al., 2017; Kogut, 2019). Ionophores are incompatible with some antibiotics like erythromycin, chloramphenicol, and tiamulin, and some sulphonamides and antioxidants (Dowling, 1992). Despite ionophores may no longer be acceptable for use, they are still permitted for broilers in some European countries. In other countries, using prophylactic anticoccidial or antibacterial drugs is forbidden according to the legislation for "drugfree" broiler chickens (Gaucher et al., 2015).

Despite the acceptance and success of anticoccidials in managing coccidiosis in the poultry industry, there is great pressure to reduce their dependence for controlling such infection (Tsiouris et al., 2013). Not surprisingly, the widespread and continuous long-term use of anticoccidials, especially in feed, generates the development of resistant Eimeria strains against most of the commercially used products (Abbas et al., 2011). In addition, the accumulation of drug residues in the meat, eggs, and by-products of poultry induces an adverse effect on public health safety (Peek and Landman, 2011).

\section{Application programs}

There are different programs for applying anticoccidials. The continuous program means using the same anticoccidial drugs until the development of drug resistance problems or until the introduction of new drugs in the field. However, long exposure to the drug leads to loss of sensitivity, so it should be kept short if possible. A drug rotation program, with continuous monitoring of the oocysts in the droppings or the litter, is very crucial to avoid the cross-resistance between anticoccidial drugs. The rotation program involves changing the anticoccidial drug every 2 months or giving it for 2 fattening periods, and it is very effective if drugs with a different mode of action follow each other. The shuttle program uses two or more anticoccidial drugs during the grow-out period of the flock (ionophore/chemical). For instance, one drug is used for the starter phase, while another one is used during the grower and finisher phases. However, it should be taken into consideration the withdrawal period of the used drug during the finisher period. This program is also very important to prevent drug resistance development. Changing the anticoccidial drug at each restocking in one operation is termed a switch system.

The resistance to anticoccidial medicaments is detected by the anticoccidial index method (Jeffers, 1974). This index depends on the detection of the survival and the relative weight gain percentages, the lesion score, and the oocyst count along with the pathological, parasitological, and production traits (McManus et al., 1968). However, the difference in weight between day 0 and day 7 after Eimeria challenge and then subtracted the average score of dropping abnormality (0-4), divided by 10 is another evaluation criteria (Jeffers, 1974). Besides, the former protocol was modified and assigned as a cut-off for drug sensitivity (Chapman and Shirley, 1989).

Application of less intensive rotation and shuttle programs and incorporating other methods in disease prevention, such as vaccination, especially in broiler breeders, or using natural products are promising to reduce the development of anticoccidial drug resistance.

\section{Vaccination}

Searching for alternative strategies to prevent coccidiosis is increasing as a result of the rapid development of anticoccidial drug resistance, the deficiency of new anticoccidials, the sensitivity of turkeys to ionophore toxicity, and the trend toward reducing using antibiotics in feed (Hafez, 2008). Vaccines against coccidiosis were not developed in the poultry industry till the 1960s. Now, the development and the use of these vaccines as well as the knowledge about the induced immunity in the vaccinated host are increasing (Williams, 2002).

Live vaccines against coccidiosis are given to the birds for the stimulation of immunity to the specific Eimeria species present in the vaccine (Price et al., 2015). This immune response can be achieved after trickle infection of birds with either a single high dose or multiple low doses of Eimeria species vaccine (Long et al., 1986). It is very important to withdraw the anticoccidial drugs 
from the feed before vaccination with a drug-sensitive live vaccine to avoid vaccination failure.

The available vaccines contain live $E$. acervulina, $E$. maxima, E. tenella, E. necatrix, E. brunetti, E. mitis, and E. praecox oocysts. Recycling of oocysts present in these vaccines through litter reinfection is essential for the development of the flock's immunity (Price et al., 2016). Therefore, the application of live vaccines in layer chickens is difficult. Moreover, live vaccines may revert to their virulence by repeated fecal-oral recycling in the susceptible host and cause severe clinical picture of coccidiosis with high mortalities (Williams, 2002).

\section{Live non-attenuated vaccines}

In 1950, the first generation of the live wild-type (non-attenuated, virulent) vaccine containing sporulated $E$. tenella oocysts was developed. It has been used in the USA and other countries for many years. Coccivac ${ }^{\circledR}$ vaccine is regarded as the first commercially available type of virulent vaccine. Variants (Coccivac-B and Coccivac-D) types are different mixtures of Eimeria species; while type " $\mathrm{T}$ " is used for turkeys and was introduced in the 1970s (Milbradt et al., 2014). Furthermore, Immucox ${ }^{\circledR}$ and Immuncox $-\mathrm{T}^{\circledR}$ were developed in Canada and have been used. Other live nonattenuated vaccines such as $\operatorname{CoxATM}^{\circledR}$, Advent TM, and Inovocox ${ }^{\mathrm{TM}}$ have been developed recently. It has been found that $\operatorname{CoxATM}^{\circledR}$ contains a mixture of wild-type Eimeria species and it is relatively tolerant to anticoccidial ionophores (Vermeulen et al., 2001). Moreover, Advent ${ }^{\mathrm{TM}}$ has more viable sporulated oocysts than other vaccines, while Inovocox ${ }^{\mathrm{TM}}$ is used in ovo. Live virulent vaccines give a specific immunity to the homologous Eimeria strain that is present in the vaccine after repeated administration in low doses. There is little or no immune protection against infection with a heterologous or different Eimeria species, and even infection with a different strain of the same species can escape immune protection (Blake et al., 2011). Nevertheless, by the time, other Eimeria species oocysts were incorporated in these vaccines to give broad-spectrum immune response (Williams, 2002). These live virulent vaccines are administrated as a direct spray for day-old chicks in the hatchery, spraying of feed, or in the drinking water in an edible gel (Jenkins et al., 2013). Strict application protocol should be applied (Chapman et al., 2002). In order to diminish the risk of coccidiosis outbreaks following vaccination, attenuated vaccines have been developed. However, the uniform up-taking and distribution of oocysts is not always obtained. Application of chemical anticoccidials after vaccination was recommended to decrease the possibility of disease outbreak after vaccination pressure and control the inherent pathogenicity of the parasites (Quiroz-Castañeda and Danta'n-Gonza'lez, 2015).

\section{Live attenuated vaccines}

As a result of the disadvantages of live virulent vaccines, the second generation of vaccines using live attenuated lines of Eimeria oocysts named precocious development has been developed at the end of the 1980s (Shirley and Bedrnik, 1997). Precocious Eimeria strains mean those lines with a shortened prepatent period of the endogenous life cycle due to the lack of one or more secondary schizogony stages, compared to strains with the normal life cycles (Mathis et al., 2017). As a result of the disappearance of the last generations of schizogony, the number of schizogony generations is decreased, and consequently, the number of the produced oocysts is reduced and the immunizing potential is maintained (McDonald et al., 1986). This vaccine was introduced commercially in the European Union as Paracox ${ }^{\circledR}$ and Livacox ${ }^{\circledR}$ products. This attenuation can be achieved by serial passages of the protozoon in chicken embryos. Attenuated vaccines contain a mixture of different sporulated oocysts of Eimeria species. It has been shown that most attenuated lines notably highly pathogenic species of E. brunetti and E. necatrix were less fecund than their wild-type equals (Shirley et al., 1986). The attenuated anticoccidial vaccine is given orally like a live virulent type. Although these precocious lines of live vaccines displayed low pathogenicity, they maintained some immunogenicity (McDonald and Ballingall, 1983) which called for their use with adjuvants (Ahmad et al., 2016).

\section{Recombinant vaccines}

The demand for the development of recombinant or sub-unit vaccines emerges (Blake et al., 2017). Recombinant vaccines against coccidiosis include different Eimeria species antigens which have immunogenic properties to stimulate the effective immune response. There are different studies regarding the use of this type of vaccine for controlling chickens coccidiosis (Yin et al., 2015). The recombinant vaccine is highly appreciated as it gives protection against many Eimeria species. However, the genetic diversity of antigens present in recombinant vaccines and the ineffectiveness of the vaccine to compete for co-infection of Eimeria species have led to different modifications of it. Accordingly, sub- 
unit vaccines emerged. Subunit vaccines comprise purified antigenic determinants obtained from Eimeria species. They rely on DNA recombinant techniques and contain protective antigens or recombinant proteins of different stages of Eimeria life cycle (sporozoites, merozoites, and gametes). The native antigens are micronemes, rhoptries, or refractile bodies of Eimeria. A sub-unit vaccine, such as CoxAbic ${ }^{\circledR}$, has been prepared from purified native protein isolated from the gametocyte of E. maxima (Wallach et al., 1995). Although this vaccine inhibits oocytes development, it provided only 53\% protection against Eimeria challenge (Sharman et al., 2010). Lal et al. (2009) showed that the specific proteins of E. tenella oocysts, sporozoite, and second-generation merozoite in each stage and many other proteins were shared in all stages. During the invasion of the protozoon, RON2 and RON5 proteins are expressed and may have a role in the host adhesion during the invasion process. In silico analysis was useful to detect epitopes from the sporozoites and merozoites as different epitope mapping of T-cell mediated antigenic determinants (Ahmad et al., 2016). Finger and Michael (2005) reported that intramuscular twice vaccination of broiler breeder chickens with sub-unit E. tenella vaccine provided maternal antibodies to the offspring and the developed immunity to Eimeria species has been demonstrated with E. acervulina, E. tenella, E. maxima, and E. mitis. Multivalent T-cell epitopes of E. tenella, E. necatrix, E. acervulina, and E. maxima vaccines were effective in improving the body weight gain, decreasing lesion scores and oocysts shedding, and increasing the anti-coccidial index (Song et al., 2015a). Moreover, multivalent sub-unit vaccine that included recombinant antigens from the previous Eimeria species has been shown partial protection against the disease caused by these species (Song et al., 2015b). Up to now, recombinant or sub-unit vaccines show limited potentiality as no antigen can induce a potent protective immune response against Eimeria infection. In addition, more immunological studies are required to investigate the hostparasite interactions at the molecular and cellular levels. In the future, a good knowledge of the proteome of E. tenella genome can allow the preparation of potential immunogens (Reid et al., 2014).

Anticoccidiosis vaccines have been used commercially in European Union since the 1990s, especially for breeder and layer flocks, followed by their use for broilers chickens (FEFAC, 2007).

Vaccines can replace drug-resistant field Eimeria strains with drug-sensitive vaccine strains. This is observed in the renovation of sensitivity to some ionophores (such as salinomycin and monensin) and synthetic chemicals like diclazuril. Nowadays, the rotation of vaccines with conventional anticoccidial drugs is used. For instance, chemical anticoccidials that are used to a single cycle of the flock can effectively reduce the oocysts load, and then in the following cycles, vaccines are used to repopulate the flock with anticoccidial-sensitive oocysts, which are highly sensitive to the chemicals and ionophores programs. Ionophores could be used after the vaccination cycles in the vaccine-repopulated flock. The addition of essential oils to the diet enhanced the productive performance of anti-coccidiosis-vaccinated broiler chickens (Lee et al., 2020).

\section{Assessment of anticoccidial vaccines}

The ideal anticoccidial vaccine should be safe, stable, easy to administer and it should also indicate the rapid onset of immunity particularly for broiler chickens, and long duration of immunity, especially in layers. Assessment of anticoccidial vaccine efficacy is based on the measurement of different evaluation criteria. These criteria include reduction of the clinical disease picture and the intestinal lesion score (Johnson and Reid, 1970), improving the weight gain, growth rate, and egg production (Williams and Catchpole, 2000), as well as decreasing the oocysts count in the droppings or litter (Hamzic et al., 2015). A quantitative polymerase chain reaction (PCR) has been developed to quantify the oocyst counts and the number of Eimeria genomes in the tissue's samples (Vrba et al., 2010). Deep sequencing or Eimeria species $18 \mathrm{~S}$ rDNA PCR amplicons is also a highly sensitive recent technique for the detection of the parasite (Hinsu et al., 2018). Some studies have used the anticoccidial index as a means of evaluating the vaccine efficacy with different cut-off values (Zhai et al., 2016). Evaluation of the immune response to the tested anticoccidial vaccine faces some difficulties as the protozoon of Eimeria is an intracellular parasite and the production of antibodies is not a reliable correlate of protection against coccidiosis (Lillehoj and Ruff, 1987). Although the level of circulating Eimeria species-specific immunoglobulin Ig (Y), IgM, and IgA were serologically detected (Gilbert et al., 1988). Eimeria infection depends mainly on the stimulation of cell-mediated immunity, so measuring this type of immune response to anticoccidial vaccines is more important than measuring humoral immunity.

\section{In ovo vaccination}


Nowadays, advanced industrial technologies regarding vaccine deliveries have been developed in poultry production systems (Saeed et al., 2019; Attree et al., 2021). The in ovo application of vaccines is applied against several diseases of poultry including coccidiosis (Saeed et al., 2019). Vaccines are inoculated into 18-daysold embryos in the hatchery. This technique is attractive for the mass administration of Eimeria vaccines (Watkins et al., 1995). Such approach for vaccines application shows many advantages including early protection of chickens with minimal interference with maternal antibodies, accurate pre-hatch vaccine delivery before exposure to environmental challenge, stimulation of innate and adaptive immunity, reduction of bird's stress, and improvement of bird's health (Sundar et al., 2016). Early age protection against certain Eimeria species can be achieved via in ovo application of a single dose of live vaccine containing oocysts of E. acervulina, E. tenella, and E. maxima (Inovocox ${ }^{\mathrm{TM}}$ ) (Dalloul and Lillehoj, 2006). Injection of the later vaccine in ovo induced significant positive effect on the hatchability and the hatched chick quality (Sokale et al., 2016) as well as improved the growth performance parameters and reduced the mortalities in hatched broiler chickens (Sokale et al., 2017). Moreover, in ovo inoculation of recombinant proteins and cytokine adjuvants conferred protection against E. tenella and E. acervulina (Lillehoj et al., 2005) and E. maxima (Lee et al., 2010). In ovo vaccination with EtMIC2 recombinant gene of E. tenella was found to stimulate the intestinal protective immunity against this infection (Ding et al., 2005).

\section{Limitations of anticoccidial vaccines.}

Vaccination against coccidiosis in chickens shows several limitations and obstacles, such as high production costs, time-consuming, adverse effects on feed efficiency and body weight gain, and the possibility of the insufficient immune response or clinical coccidiosis as a result of dosage errors (Dalloul and Lillehoj, 2006). The genomic studies of Eimeria species especially E. tenella have indicated a wide antigenic variability that leads to the rapid development of vaccine resistance. Besides, production of either live virulent or attenuated anticoccidial vaccines is limited by some factors, including the need for chickens' infection to produce oocysts, quality control tests for ensuring vaccine safety, short shelf life time of the vaccines, loss of infectivity with time affecting their expiry, and the need for cold environment condition for storage. Another point of concern is the reversal of virulence of coccidiosis live vaccines. The inaccurate addition of anticoccidial medicaments to the feed hinders effective vaccination of drug-sensitive strains and vaccination of diseased birds. However, stoppage of oocysts production following vaccine challenge is very critical to obtain sterile immunity and prevent vaccine resistance (Blake et al., 2017).

\section{Natural controlling}

As a result of raised awareness and demand of consumers for chemical-free animal products, the necessity to find more acceptable, and more environmentally friendly natural compounds alternatives against avian coccidiosis have been increased (Bozkurt et al., 2013). Some of these natural alternatives are probiotics, prebiotics, and phytobiotics (phytogenics or botanicals). These natural alternatives are applied in the feed or water or recently inoculated in ovo during embryogenesis (Saeed et al., 2019).

\section{Probiotics}

Probiotics refer to beneficial bacteria or even yeast that are mostly used in the feed to improve the immune system and decrease the bacterial intestinal pathogens load. The effect of different types of probiotics on Eimeria species infection of poultry is summarized in Table 1. Lactobacillus-based probiotic reduced the shedding of oocysts and increased $\mathrm{T}$ and $\mathrm{B}$ cell specific cytokines against E. avervulina infection (Dalloul et al., 2005). Similarly, Pediococcus and Saccharomyces-based probiotics revealed improving in performance parameters after a challenge with E. tenella and E. acervulina (Lee et al., 2007). In addition, Saccharomyces and Lactobacillusbased probiotics can enhance the immune response and performance parameters after a challenge with Eimeria in broiler chickens (Awais et al., 2019). Probiotics composed of Bifidobacterium animalis and Lactobacillus salivarius alleviate the damaging effects of Eimeria infection but enhance the performance parameters of infected chickens (Ritzi et al., 2014). Furthermore, single or mixed combinations of probiotics could reduce coccidiosis lesion scores. Exogenous enzymes combined with probiotics containing Bacillus species reduced the intestinal damage and performance loss caused by Eimeria challenge (Dersjant-Li et al., 2016). The combined effect of the probiotics with the vaccines, anticoccidials, or even with the plant extracts have also been demonstrated with successful results (Chen et al., 2016; Wang et al., 2019). 
Table 1. The effect of different types of probiotics on Eimeria infections in poultry

\begin{tabular}{|c|c|c|}
\hline Probiotic bacteria & Anticoccidial action & Reference \\
\hline \multirow{5}{*}{$\begin{array}{l}\text { A mixture of lactic } \\
\text { acid bacteria } \\
\text { (Lactobacillus } \\
\text { species) }\end{array}$} & $\begin{array}{l}\text { Lacto-bacillus species treatment could enhance intestinal health and integrity, feed } \\
\text { digestion and absorption, and body weight gain as a result of the competitive exclusion } \\
\text { against Eimeria species. }\end{array}$ & $\begin{array}{l}\text { Behnamifar et al. } \\
(2019)\end{array}$ \\
\hline & $\begin{array}{l}\text { These bacteria improve the permeability of the intestinal cells, regulate the mucosal } \\
\text { barrier by mucin in the intestinal wall, promote the balance of gut microbiota, increase } \\
\text { nutrient utilization, and thus hinder the intestinal colonization and invasion of } \\
\text { protozoon. }\end{array}$ & Royan (2019) \\
\hline & $\begin{array}{l}\text { Eimeria species adhere to the intestinal cell surface receptors. However, lactic acid } \\
\text { bacteria absorb receptors in the epithelial cells, compete for the parasite and prevent its } \\
\text { intestinal invasion. This attachment hampers the perforation of sporozoites into the } \\
\text { intestinal mucosa, resulting in reduced proliferation and consequently oocyst shedding. }\end{array}$ & $\begin{array}{l}\text { Alagawany et al. } \\
(2018)\end{array}$ \\
\hline & $\begin{array}{l}\text { Competitive exclusion of the parasites at the attachment receptor sites, lactic acid } \\
\text { bacteria co-aggregate with the parasite and produce some antimicrobials such as lactic } \\
\text { acid, hydrogen peroxide, and bacteriocins which stimulate the immune system. }\end{array}$ & $\begin{array}{l}\text { Jarujareet et al. } \\
(2018)\end{array}$ \\
\hline & $\begin{array}{l}\text { The growth-promoting effect of Lactobacillus-based probiotics in Eimeria-infected } \\
\text { chickens is owing to the enhancement of both cellular and humoral immune responses } \\
\text { that restrict the gut invasion with the parasite. Lactobacillus-based probiotics produce } \\
\text { cytokines (IL-2, IL-6, and IFN-c) and local (mucosal) immunoglobulin Ig (A), which } \\
\text { are important for challenging coccidiosis. Cytokines are a natural protein that is } \\
\text { essential for stimulation and regulation of immunity as well as hindering siderophores } \\
\text { secretion and restricting iron availability to facilitate parasite invasion. }\end{array}$ & Khan et al. (2019) \\
\hline \multirow[t]{2}{*}{ Bacillus cereus } & $\begin{array}{l}\text { - It competes with the parasite via improving the ability of beneficial bacteria to } \\
\text { adhere to the gut epithelium and occupy most of the cell receptors, and accordingly } \\
\text { inhibit the parasite's growth. } \\
\text { - This species helps in the digestion of indigestible fibers and releasing of some } \\
\text { substances like butyrate and fatty acids, which are essential for extra nutrients and } \\
\text { energy. } \\
\text { - It is also essential for stimulating the proliferation of the intestinal epithelium. }\end{array}$ & Leung et al. (2018) \\
\hline & $\begin{array}{l}\text { It enhances the host immune response via the regulation of T-helper cells that provides } \\
\text { protection against Eimeria challenge. }\end{array}$ & Gu et al. (2019) \\
\hline \multirow[t]{2}{*}{ Bacillus subtilis } & $\begin{array}{l}\text { It modifies the composition of the gut microbiota, improves the growth performance and } \\
\text { nutrient digestion via increasing the number of Bacteroidetes and other normal } \\
\text { inhabitant bacteria in broilers. Besides, it lowers the bacterial diversity in the caecum } \\
\text { via changing microbial communities and increasing predominant species. }\end{array}$ & $\begin{array}{l}\text { Erdoğmus et al. } \\
(2019)\end{array}$ \\
\hline & $\begin{array}{l}\text { It enhances the host immune response via the regulation of T-helper cells that provide } \\
\text { protection against Eimeria challenge. }\end{array}$ & Wang et al. (2019) \\
\hline $\begin{array}{l}\text { Enterococcus } \\
\text { faecium }\end{array}$ & $\begin{array}{l}\text { - Enterococcus faecium could increase the number of beneficial intestinal microflora } \\
\text { and modulate their composition. } \\
\text { - In addition, it has an immunomodulatory effect in chickens after infection with } \\
\text { Eimeria species through increasing the production of anti-inflammatory cytokines and } \\
\text { other immune mediators such as IL-1b, IL-6, IL-10, and IFN-c, which leads to reducing } \\
\text { of the severity of the intestinal lesions. }\end{array}$ & Wu et al. (2019) \\
\hline Pediococcus & $\begin{array}{l}\text { Pediococcus alone and/or combination Saccharomyces increase the immune response } \\
\text { against E. acervulina and E. tenella, with protection against growth retardation and } \\
\text { oocyst shedding. }\end{array}$ & Lee et al. (2007) \\
\hline
\end{tabular}

\section{Prebiotics}

Prebiotics are non-digestible feed ingredients that enhance the growth of probiotics and their activities in the gut of birds (Bindels et al., 2015). Mannan oligosaccharides, fructooligosaccharides, $\beta$-glucans, arabinoxylooligosaccharides, soy oligosaccharides, isomatooligosaccharides, inulin, and pyrodextrins are the common types of prebiotics that used in the poultry industry (Nopvichai et al., 2019; Ocejo et al., 2019). Dietary addition of mannan oligosaccharides originated from the cell wall of Saccharomyces cerevisiae (yeast) that can reduce the severity of E. tenella (Elmusharaf et al., 2006), and E. acervulina infections in the challenged birds (Elmusharaf et al., 2007). Prebiotics may have similar anticoccidial mechanisms to probiotics. They suppress coccidiosis probably through indirect regulation 
of increased probiotics and host immunity. Prebiotics mediated the immune response owing to their interaction with gut immune cells. Furthermore, they enhance gut colonization with probiotics and their products that interact with immune cells and consequently suppress pathogens (Sugiharto, 2014). The host can produce bacteriocins and other immunomodulators that stimulate macrophages to neutralize the pathogens (Alloui et al., 2013). Bozkurt et al. (2014) demonstrated that prebiotics can diminish the coccidial infection in chickens but reserve oocyst production that might act as a source of a live vaccine for non-infected birds.

\section{Phytobiotics}

Products that are produced or extracted from plants, essential oils, or oleoresins could be defined as phytobiotics (Gadde et al., 2017; Mohammadi Gheisar and Kim, 2017; Skoufos et al., 2020). Herbs produce a variety of phytochemicals as alkaloids, phenolics, polysaccharides, polyacetylenes, ethanol, petroleum, ether and acetone extracts, terpenoids, ground powder, essential oils, and other large numbers of bioactivities (Blake and Tomley, 2014). Phytobiotics proved their strong coccidiostatic and coccciocidal efficacy in terms of a significant reduction in birds' mortalities, intestinal lesions, and improvement of the performance (Habibi et al., 2016). Phytobiotics exert a wide range of beneficial actions as alternative natural anticoccidial preparations. They increase the digestive secretions and food intake, maintain the gut health, stimulate the immune response, as well as they have growth-promoting, antimicrobial, antiinflammatory, and antioxidant properties (Jitviriyanon et al., 2016; Giannenas et al., 2018; Zhai et al., 2018). Production of superoxide dismutase enzyme by phytobiotics enhances their antioxidant activity. (Idris et al., 2017) and mitigation of Alpha-1-acid glycoprotein level which is a moderate acute-phase protein that is secreted from the hepatocytes in response to Eimeria infection (O'Reilly et al., 2018; Gordillo Jaramillo et al., 2021). Increasing the levels of phenolic compounds in chicken meat is associated with the strong antioxidant capacity (Ramos et al., 2017). There are about 68 herbs and phytocompounds with proven suppression of Eimeria species that have been demonstrated. Table 2 illustrates the commonly used phytobiotics and their action against Eimeria species infection in poultry.

The in vitro activity of a mixture of carvacrol, curcumin, and Echinacea purpurea extract showed inhibition of the invasion of epithelial cells by E. tenella sporozoites (Burt et al., 2013). The efficacy of garlic active principle (allicin) E. tenella sporozoites showed successful inhibition of the protozoon in vitro (Alnassan et al., 2015). Besides, a mixture of thymol, carvacrol, and saponins has a strong in vitro anticoccidial effect (Felici et al., 2020). A recent study by Sidiropoulou et al. (2020) revealed an anticoccidial activity of oregano and garlic essential oils in vitro.

Furthermore, combined phytochemicals supplementation can boost the anticoccidial effects in birds, compared to the time they are administered alone (Felici et al., 2020; Sidiropoulou et al., 2020). For example, the addition of mixed herbs of Holarrhena antidysenterica, Berberis aristata, Syzygium aromaticum, Polygonum aviculare, and Allium sativum to the diet of broiler chickens protected birds from E. tenella, E. maxima, and $E$. acervulina infection through enhancement of intestinal microbiome and increasing the number of Bacillales and Lactobacillales (Tsiouris et al., 2021).

The meat quality of broiler chickens is affected by challenges with Eimeria (Chodová et al., 2018). However, dietary supplementation of broilers with phytobiotics may improve the carcass trait after exposure to coccidiosis (Tauer et al., 2019).

Regardless of the phytobiotics success against coccidiosis, the little understanding about their mode of actions as well as their safety and toxicity make limitations in their field usage.

\section{Advanced industrial technologies}

Some modifications in the physical cage environment during brooding of pullets could be applied (Price et al., 2013). A mesh floor consists of a thick paper of fiber trays made of egg carton material that could be put over a portion $(40 \%)$ of the cage floor. This method reduces the possibility of oocysts multiplication on the floor. In addition, modification a manure belt to rotate and go through a scraping area where manure is scraped off the belt into a manure disposal area. Moreover, regular checking of litter moisture contents and controlling of environmental humidity surrounding chickens are critical preventive measures.

Understanding the genetic markers of Eimeria species is very essential to detect susceptibility, tolerance, and resistance traits. Such an approach has a great impact on the breeding decisions which help the control of coccidiosis in the future (Boulton et al., 2018). For instance, the susceptibility to E. tenella challenge varies according to breeds, where Egyptian Fayoumi breeds are highly resistant but White Leghorn breeding lines are susceptible (Pinard-van der Laan et al., 2009). 
Table 2. The effect of different types of phytobiotics on Eimeria species infection of poultry

\begin{tabular}{ll}
\hline Phytobiotic & Active compo \\
\hline & \\
& $\begin{array}{l}\text { Artemisinin } \\
\text { Artemisia annua }\end{array}$ \\
Artemisia sieberi & $\begin{array}{l}\text { Phytochemicals, } \\
\text { flavonoids, and } \\
\text { phenols }\end{array}$ \\
&
\end{tabular}

Anticoccidial action

- Directly, artemisinin degenerates the iron-peroxide complex and generates reactive oxygen species which directly inhibits sporulation and cell wall formation in Eimeria species, leading to an intervention in the life cycle of the parasite and reduction of the lesion score.

- Moreover, artemisinin has an adverse effect on the gametocyte of E. tenella through limiting of sarcoplasmic-endoplasmic reticulum calcium ATPase enzyme expression.

- Indirectly, other compounds of the plant establish the growth of other beneficial intestinal microflora that improve the digestion and absorption of food as well as they enhance the immune response.

- Allicin and sulfur induce alterations in broiler intestinal microbiota and have antioxidant activity against Eimeria oocysts in broiler chickens.

- They inhibit the sporulation of E. tenella effectively in vitro. Also, they improve the growth performance and intestinal microbiota, and decrease the clinical picture and the fecal oocyst output of Eimeria in vivo.

- The highest capacity of the intestinal villi and crypts was reported after dietary supplementation of Eimeria infected broilers with garlic.

Allicin

Garlic

(Allium sativum)

\section{Sulfur}

Propyl thiosulfinate

Propyl thiosulfinate oxide

Dietary supplementation of Eimeria infected broilers with a combination of garlic and ginger (Zingiber officinale) improved the intestinal morphology and the integrity as well as the mucosal architecture in terms of increasing villus height and decreasing crypt depth.

Propyl thiosulfinate and propyl thiosulfinate oxide modify the expression levels of 1,227 transcripts related to intestinal intraepithelial lymphocytes in chickens. Besides, they activate NF- $\kappa$ B transcription factor that plays an important role in the regulation of immune response after infection. Accordingly, these compounds increase the resistance to Eimeria species infections by boosting the humoral immunity or stimulating splenocyte proliferation which directly leads to the destruction of sporozoites.

- Curcumin has a strong anticoccidial activity via destructing of sporozoites, the interference with Eimeria life cycle, enhancing the host humoral immunity, and maintaining gut integrity.

- In addition, it affects the microbial population by increasing the abundance of

Curcuma longa (turmeric)

Curcumin

(Diferuloylmethane) Lactobacilli and reducing the population of Selenihalanaerobacter in the chickens' gut.

Curcumin has antioxidative characters through inhibition of nitic oxide induction by macrophages stimulated with lipopolysaccharide and interferon. Nitic oxide may promote the development of Eimeria lesions.

Ali et al. (2019)

Jiao et al. (2018)

Reference

- These compounds interfere with the life cycle of Eimeria species by destroying sporozoite membrane, decreasing the number of oocysts in the litter, increasing the growth performance and intestinal barrier function, as well as altering the gut physiology.

- Moreover, they increase the volatile fatty acids concentration in the caecum following the challenge with coccidiosis vaccine in broilers.

(Origanum vulgare) Carvacro

Eugenol

These compounds enhance the carcass traits of broiler chickens after exposure to coccidiosis.

- The anticoccidial action of Bidens pilosa is related to the presence of some phytochemicals, such as 70 aliphatics, 60 flavonoids, 25 terpenoids, 19 phenylpropanoids, 13 aromatics, 8 porphyrins, and 6 other compounds.

- Polyacetylenes and flavonoids showed anti-parasitic effects via disruption of

the life cycle of Eimeria and enhances T-cell mediated immunity.

Bidens pilosa Polyacetylene

The plant exhibits anticoccidial activity in chickens infected with $E$. tenella as demonstrated by reduction of mortalities, oocyst count, and intestinal lesions, increasing body weight and gut microflora, and improving the intestinal villus to crypt ratio.

The polysaccharide acemannan has an immunomodulatory effect through binding with mannose receptor on macrophages, stimulating cells for production of some inflammatory cytokines like IL- 1 through IL- 6 and TNF- $\alpha$ and finally

Aloe vera

Aloe excelsa

Acemannan

inhibiting Eimeria infection.

Treatment with Aloe vera showed increased weight gain and decreasing droppings oocyst count of infected chickens.

It improves chicken growth performance and alters caecal microbiota composition.

$\begin{array}{ll}\text { Cinnamon } & \text { Cinnamaldehyde } \\ \text { (Cinnamomum } & \text { Acids } \\ \text { zeylanicum) } & \text { Numerous essential } \\ & \text { oils }\end{array}$

Cinnamaldehyde and Oleoresins (Capsicum and Turmeric) can regulate host innate immunity against Eimeria species in chickens by enhancing and elevation of T helper cells and cytokines (FN-c and IL-6) and body weight gain.
Pop et al. (2019)

Tauer et al. (2019)

Majed et al.

(2019)

Hussein et al.

(2021)

Yadav and Jha

(2019)

Lee et al. (2020)

Yang et al.

(2019)

Chen et al.

(2020)

Akhtar et al.

(2012)

Babak and Nahashon (2014)

Yang et al. (2020)

Lee et al. (2011) 


\begin{tabular}{|c|c|c|c|}
\hline Beet (Beta vulgaris) & Betaine & $\begin{array}{l}\text { - Betaine stabilizes and protects the metabolism of the intestinal epithelial cells } \\
\text { in which Eimeria species multiply. } \\
\text { - It can protect cells against the stress of osmosis via stabilization of cell } \\
\text { membranes and enabling osmotic pressure maintenance in the intestinal cells } \\
\text { with normal metabolic activity. } \\
\text { - It affects the developing stages of Eimeria. Betaine and/or combination with } \\
\text { salinomycin inhibited the invasion of sporozoites and the second generation } \\
\text { schizonts for E. acervulina and E. tenella. } \\
\text { - Betaine increases the lymphocytes and phagocytes in the intestine of } \\
\text { Eimeria-infected chickens. } \\
\text { - The palliative effect of betaine on the coccidiosis appeared as an } \\
\text { improvement of weight gain and feed efficiency. }\end{array}$ & $\begin{array}{l}\text { Klasing et al. } \\
(2002)\end{array}$ \\
\hline $\begin{array}{l}\text { Wheat bran (Triticum } \\
\text { aestivum) } \\
\text { Sugar Cane (Saccharum } \\
\text { officinarum) }\end{array}$ & Arabinoxylans & $\begin{array}{l}\text { Arabinoxylans protect chickens against Eimeria infection through stimulation of } \\
\text { natural (adaptive) cell-mediated immune response. This protection was indicated } \\
\text { by improving body weight gain and diminishing oocyst shedding, intestinal } \\
\text { lesion score, and anticoccidial indices. }\end{array}$ & $\begin{array}{l}\text { Awais and } \\
\text { Akhtar (2012) }\end{array}$ \\
\hline $\begin{array}{l}\text { Pine tree (Pinus } \\
\text { radiata) }\end{array}$ & Tannins & $\begin{array}{l}\text { Concentrated tannins penetrate Eimeria oocyst wall and damage the cytoplasm } \\
\text { through the inactivation of endogenous enzymes responsible for the sporulation } \\
\text { of the oocyst. Accordingly, abnormal shapes of sporocysts and inhibition of the } \\
\text { life cycle of E. tenella, E. maxima, and E. acervulina can occur. }\end{array}$ & $\begin{array}{l}\text { Molan et al. } \\
(2009)\end{array}$ \\
\hline $\begin{array}{l}\text { Green tea (Camellia } \\
\text { sinensis) }\end{array}$ & $\begin{array}{l}\text { Selenium and } \\
\text { polyphenols }\end{array}$ & They inactivate the enzymes responsible for Eimeria oocyst sporulation. & $\begin{array}{l}\text { Molan and Faraj } \\
(2015)\end{array}$ \\
\hline Carica papaya & Papain & $\begin{array}{l}\text { - Papain may have a proteolytic destructive activity against Eimeria. } \\
\text { - It has an inflammatory suppression by vitamin A. }\end{array}$ & $\begin{array}{l}\text { Nghonjuyi et al. } \\
(2015)\end{array}$ \\
\hline $\begin{array}{l}\text { Olive tree }(\text { Olea } \\
\text { europaea })\end{array}$ & Maslinic acid & $\begin{array}{l}\text { Maslinic acid was found to reduce the lesion, the oocyst, and the anticoccidial } \\
\text { indices in Eimeria infected chickens. Its mechanism as an anticoccidial plant } \\
\text { extract is well not known. }\end{array}$ & $\begin{array}{l}\text { De Pablos et al. } \\
(2010)\end{array}$ \\
\hline $\begin{array}{l}\text { Guar bean (Cyamopsis } \\
\text { tetragonoloba) }\end{array}$ & Saponins & $\begin{array}{l}\text { Saponins could bind with sterol molecules of the parasite cell membrane and lyse } \\
\text { oocysts. }\end{array}$ & $\begin{array}{l}\text { Hassan et al. } \\
(2008)\end{array}$ \\
\hline Grape seed & Proanthocyanidin & $\begin{array}{l}\text { - Proanthocyanidin has polyphenolic antioxidant character. It alleviates } \\
\text { coccidiosis by downregulation of oxidative stress via increasing the superoxide } \\
\text { dismutases in the host blood and decreasing the nitric oxide. } \\
\text { - It has been shown that grape seed proanthocyanidin reduced E. tenella } \\
\text { infection in terms of improvement of the intestinal pathology, and body weight, } \\
\text { and reduced mortality in broiler chickens. }\end{array}$ & $\begin{array}{l}\text { Wang et al. } \\
(2008)\end{array}$ \\
\hline $\begin{array}{l}\text { Berberis lyceum } \\
\text { Linum usitatissimum } \\
\text { Ageratum conyzoides } \\
\text { Vernonia amygdalina }\end{array}$ & Berberine & $\begin{array}{l}\text { Berberine inhibits E. tenella sporozoites by induction of oxidative stress. The } \\
\text { later causes the imbalance of oxidant or antioxidant species in the host which is } \\
\text { often seen in coccidiosis. Once Eimeria sporozoites invade the intestinal } \\
\text { epithelial cells of the host, the reactive nitrogen species and the reactive oxygen } \\
\text { species are produced, leading to the death of non-sporulated oocysts. }\end{array}$ & $\begin{array}{l}\text { Nweze and } \\
\text { Obiwulu (2009) }\end{array}$ \\
\hline $\begin{array}{l}\text { Tremella fuciformis } \\
\text { Astragalus } \\
\text { membranaceus Radix } \\
\text { Carthamus tinctorius } \\
\text { Lentinus edodes }\end{array}$ & Polysaccharides & $\begin{array}{l}\text { - Polysaccharides augment the anticoccidial antibodies and antigen-specific } \\
\text { splenocytes proliferation in splenocytes through cell-mediated and humoral } \\
\text { immunity against coccidiosis. } \\
\text { - Besides, polysaccharides stimulate lymphocytes proliferation through the } \\
\text { regulation of DNA polymerase activity. } \\
\text { - Polysaccharides treated vaccinated birds showed better growth and lower } \\
\text { Eimeria oocysts count when compared to non-treated vaccinated ones. }\end{array}$ & Guo et al. (2005) \\
\hline $\begin{array}{l}\text { A mixture of } \\
\text { cinnamaldehyde, } \\
\text { carvacrol, Capsicum } \\
\text { Oleoresin, and } \\
\text { Turmeric Oleoresin }\end{array}$ & & $\begin{array}{l}\text { This mixture exhibits immuno-stimulatory activity through increasing in NK } \\
\text { cells, macrophages, CD4+ T cells, CD8+ T cells, and their cytokines (IFN- } \gamma \text { and } \\
\text { IL-6) and decreasing in TNFSF15 and IL-17F, leading to the destruction of } E \text {. } \\
\text { tenella in chickens. }\end{array}$ & Lee et al. (2011) \\
\hline $\begin{array}{l}\text { Oriental Plum fruit } \\
\text { (Prunus salicina) }\end{array}$ & Phenols & $\begin{array}{l}\text { Phenols significantly increased the transcription of IFN- } \gamma \text { and IL-15 and } \\
\text { splenocyte proliferation, resulting in enhancing immunity against coccidiosis. } \\
\text { Dietary addition of it to chickens feed significantly reduced E. acervulina } \\
\text { infection in chickens in terms of increased body weight gain and reduced fecal } \\
\text { oocyst shedding. }\end{array}$ & Lee et al. (2008) \\
\hline $\begin{array}{l}\text { Mushroom } \\
\text { (Fomitella fraxinea) }\end{array}$ & Lectins & $\begin{array}{l}\text { - Lectins boost both cellular and humoral immune responses of chickens } \\
\text { against coccidiosis and other infectious pathogens and toxins. Besides, it } \\
\text { enhances the growth performance parameters. } \\
\text { - When inoculated lectins in } 18 \text {-day-old embryos can protect week-old chicks } \\
\text { after Eimeria challenge against weight loss with a reduction in oocysts shedding } \\
\text { compared to untreated embryos. }\end{array}$ & $\begin{array}{l}\text { Dalloul et al. } \\
(2006)\end{array}$ \\
\hline Dichroa febrifuga & $\begin{array}{l}\text { Febrifugine (alkaloid) } \\
\text { Halogenated derivative } \\
\text { of Febrifugine } \\
\text { "Halofuginone" }\end{array}$ & $\begin{array}{l}\text { Febrifugine is a strong anti-coocidal chemical and proved its efficacy against } E \text {. } \\
\text { tenella infection in chickens. }\end{array}$ & $\begin{array}{l}\text { Zhang et al. } \\
(2012)\end{array}$ \\
\hline $\begin{array}{l}\text { Areca Nut } \\
(\text { Areca } \text { Catechu) }\end{array}$ & $\begin{array}{l}\text { Arecoline Guvacine } \\
\text { (Alkaloids) }\end{array}$ & $\begin{array}{l}\text { It enhances immunity through the production of IL-2 and reduces the caecal } \\
\text { lesion scores. }\end{array}$ & $\begin{array}{l}\text { Wang et al. } \\
(2018)\end{array}$ \\
\hline
\end{tabular}




\begin{tabular}{|c|c|c|c|}
\hline $\begin{array}{l}\text { Emblica officinalis } \\
\text { Echinacea purpurea }\end{array}$ & $\begin{array}{l}\text { Tannins and chicoric } \\
\text { acid }\end{array}$ & $\begin{array}{l}\text { - Tannins and chicoric acid promote the humoral immune response in chickens } \\
\text { against coccidiosis. The mechanism of boosting the immune response is not well } \\
\text { known. } \\
\text { - The weight gain and lesions enhanced after a mixed infection with different } \\
\text { Eimeria species. }\end{array}$ & $\begin{array}{l}\text { Kaleem et al. } \\
(2014)\end{array}$ \\
\hline Citric extracts & Organic acids & $\begin{array}{l}\text { These acids inhibited different Eimeria species in terms of reduction of lesion } \\
\text { scores and oocyst production }\end{array}$ & $\begin{array}{l}\text { Tamasaukas et } \\
\text { al. (1997) }\end{array}$ \\
\hline
\end{tabular}

\section{CONCLUSION}

As the world's poultry industry continues to grow, attention toward controlling coccidiosis increases to combat such very important reported disease of chickens. Infections with Eimeria species are often associated with severe economic losses. Medication or vaccination alone is not enough for the complete eradication of the disease. However, the previous strategies should be accompanied by improvements in management, sanitation, and hygiene as well as using of some supportive natural feed additives such as probiotics, prebiotics, or phytobiotics. Regular monitoring programs are crucial for the early detection of Eimeria strains developing resistance. In addition, controlling avian coccidiosis demands many communal efforts with advanced industrial technologies to open new lines of investigations. The modifications in the physical cage environment during brooding of pullets could be applied. Regular checking of litter moisture contents and controlling of environmental humidity surrounding chickens are critical preventive measures. Genetic selection is a long-term approach that should be applied throughout generations of different avian breeds.

\section{DECLARATIONS}

\section{Competing interests}

There are no competing interests to declare.

\section{Ethical considerations}

Plagiarism, consent to publish, misconduct, data fabrication and/or falsification, double publication and/or submission, and redundancy have been checked by the author.

\section{REFERENCES}

Abbas RZ, Iqbal Z, Blake D, Khan MN, and Saleemi MK (2011). Anticoccidial drug resistance in fowl coccidia: The state of play revisited. World's Poultry Science Journal, 67: 337-350. DOI: https://www.doi.org/10.1017/S004393391100033X

Adhikari P, Kiess A, Adhikari R, and Jha R (2020). An approach to alternative strategies to control avian coccidiosis and necrotic enteritis. Journal of Applied Poultry Research, 29: 515-34. DOI: http://www.doi.org/10.1016/j.japr.2019.11.005

Ahmad TA, El-Sayed BA, and El-Sayed LH (2016). Development of immunization trials against Eimeria spp. Trials Vaccinology, 5: 3847. DOI: https://www.doi.org/10.1016/j.trivac.2016.02.001

Akhtar M, Hai A, Awais MM, Iqbal Z, Muhammad F, ul Haq A, and Anwar MI (2012). Immunostimulatory and protective effects of Aloe vera against coccidiosis in industrial broiler chickens. Veterinary Parasitology, 186: 170-177. DOI: https://www.doi.org/10.1016/j.vetpar.2011.11.059

Alagawany M, El-Hack MEA, Farag MR, Sachan S, Karthik K, and Dhama K (2018). The use of probiotics as eco-friendly alternatives for antibiotics in poultry nutrition. Environmental Science and Pollution Research, 25: 10611-10618. DOI: https://www.doi.org/10.1007/s11356-018-1687-x

Ali M, Chand N, Khan RU, Naz S, and Gul S (2019). Anticoccidial effect of garlic (Allium sativum) and ginger (Zingiber officinale) against experimentally induced coccidiosis in broiler chickens. Journal of Applied Animal Research, 47: 79-84. DOI: https://www.doi.org/10.1080/09712119.2019.1573731

Allen PC, and Fetterer RH (2002). Recent advances in biology and immunobiology of Eimeria species and in diagnosis and control of infection with these coccidian parasites of poultry. Clinical Microbiology Reviews, 15(1): 58-65. DOI: https://www.doi.org/10.1128/CMR.15.1.58-65.2002

Alloui MN, Szczurek W, and Swiątkiewicz S (2013). The usefulness of prebiotics and probiotics in modern poultry nutrition: A review. Annals of Animal Science, 13(1): 17-32. DOI: https://www.doi.org/10.2478/v10220-012-0055-X

Alnassan AA, Thabet A, Daugschies A, and Bangoura B (2015). In vitro efficacy of allicin on chicken Eimeria tenella sporozoites. Parasitology Research, 114(10): 3913-3915. DOI: https://www.doi.org/10.1007/s00436-015-4637-2

Attree E, Sanchez-Arsuaga G, Jones M, Xia D, Marugan-Hernandez V, Blake D, and Tomley F (2021). Controlling the causative agents of coccidiosis in domestic chickens; an eye on the past and considerations for the future. CABI Agriculture and Bioscience, 2(37): 10-16. DOI: https://www.doi:10.1186/s43170-021-00056-5

Awais MM, and Akhtar M (2012). Evaluation of some sugarcane (Saccharum officinarum L.) extracts for immunostimulatory and growth promoting effects in industrial broiler chickens. Pakistan Veterinary Journal, 32(3): 398-402. Available at: http://www.pvj.com.pk/abstract/32 3/398-402.htm

Awais MM, Jamal MA, Akhtar M, Hameed MR, Anwar MI, and Ullah MI (2019). Immunomodulatory and ameliorative effects of Lactobacillus and Saccharomyces based probiotics on pathological effects of eimeriasis in broilers. Microbial Pathogenesis, 126: 101108. DOI: https://www.doi.org/10.1016/j.micpath.2018.10.038

Baba E, Fukata T, and Arakawa A (1982). Establishment and persistence of Salmonella typhimurium infection stimulated by Eimeria tenella in chickens. Research Veterinary Science, 33(1): 95-98. Available at: https://pubmed.ncbi.nlm.nih.gov/6753076/

Babak D, and Nahashon SN (2014). A review on effects of Aloe vera as a feed additive in broiler chicken diets. Annals of Animal Science, 14(3): 491-500. Available at: https://digitalscholarship.tnstate.edu/cgi/viewcontent.cgi?article=12 34\&context=agricultural-and-environmental-sciences-faculty 
Badrawy A (2012). Prophylactic and therapeutic action of toltrazoril with coccivac B vaccination for prevention and control of coccidiosis in broiler chickens. Zagazig Veterinary Journal, 3: 1110-1458. Available http://www.publications.zu.edu.eg/Pages/PubShow.aspx?ID=13884 \&pubID $=18$

Behnamifar AR, Rahimi S, Kiaei MM, and Fayazi H (2019). Comparison of the effect of probiotic, prebiotic, salinomycin and vaccine in control of coccidiosis in broiler chickens. Iranian Journal of Veterinary Research, 20: 51-54. DOI: http://www.ncbi.nlm.nih.gov/pmc/articles/pmc6509914/

Belli SI, Smith NC, and Ferguson DJ (2006). The coccidian oocyst: A tough nut to crack! Trends in Parasitology, 22(9): 416-423. DOI: https://www.doi.org/10.1016/j.pt.2006.07.004

Beninca ALV, Candeias APM, Fernandes SR, and Fernandes NLM (2021). Efficiency of sanitary management of litter in Eimeria spp. control in poultry housing of Western Paraná, Brazil. Brazilian Journal of Veterinary Parasitology, 30(2): e026920. DOI: https://www.doi.org/10.1590/ S1984-29612021039

Bindels LB, Delzenne NM, Cani PD, and Walter J (2015). Towards a more comprehensive concept for prebiotics. Nature Reviews Gastroenterology and Hepatology, 12(5): 303-310. DOI: https://www.doi.org/10.1038/nrgastro.2015.47

Blake D (2015). Eimeria genomics: where are we now and where are we going? Veterinary Parasitology, 212: 68-74. DOI: https://www.doi.org/10.1016/j.vetpar.2015.05.007

Blake DP, and Tomley FM (2014). Securing poultry production from the ever-present Eimeria challenge. Trends in Parasitology, 30: 12-19. DOI: https://www. doi.org/10.1016/j.pt.2013.10.003

Blake DP, Pastor-Fernandez I, Nolan MJ, and Tomley FM (2017). Recombinant anticoccidial vaccines - a cup half full? Infection Genetics and Evolution, 55: 358-365. DOI: https://www.doi.org/10.1016/j.meegid.2017.10.009

Blake DP, Billington KJ, Copestake SL, Oakes RD, Quail MA, Wan KL, Shirley MW, and Smith AL (2011). Genetic mapping identifies novel highly protective antigens for an apicomplexan parasite. PLOS Pathogens, 7(2): e1001279. DOI: https://www.doi.org/10.1371/journal.ppat.1001279

Bozkurt M, Giannenas I, Kucukyilmaz K, Christaki E, and Florou-Paneri $P$ (2013). An update on approaches to controlling coccidia in poultry using botanical extracts. British Poultry Science, 54: 713727. DOI: https://www.doi.org/10.1080/00071668.2013.849795

Bozkurt M, Aysul N, Küçükyilmaz K, Aypak S, Ege G, Catli AU, Aksit H, Cöven F, Seyrek K, and Cinar M (2014). Efficacy of in-feed preparations of an anticoccidial, multienzyme, prebiotic, probiotic, and herbal essential oil mixture in healthy and Eimeria spp.infected broilers. Poultry Science, 93(2): 389-399. DOI: https:/www./doi.org/10.3382/ps.2013-03368

Boulton K, Nolan MJ, Wu Z, Psifdi A, Riggio V, Harman K, Bishop SC, Kaiser P, Abrahamsen MS, and Hawken R (2018). Phenotypic and genetic variation in the response of chickens to Eimeria tenella induced coccidiosis. Genetics Selection Evolution, 50(1): 1-12. DOI: https://ww.doi.org/10.1186/s12711-018-0433-7

Burt SA, Tersteeg-Zijderveld MH, Jongerius-Gortemaker BG, Vervelde L, and Vernooij JC (2013). In vitro inhibition of Eimeria tenella invasion of epithelial cells by phytochemicals. Veterinary $\begin{array}{cccc}\text { Parasitology, } & 191: & 378 . & \text { DOI: }\end{array}$ https://www.doi.org/10.1016/j.vetpar.2012.09.001

Chapman HD (1994). A review of the biological activity of the anticoccidial drug nicarbazin and its application for the control of coccidiosis in poultry. Poultry Science Review, 5: 231-243. Available at: https://agris.fao.org/agrissearch/search.do?recordID=GB9508922

Chapman HD (2014). Milestones in avian coccidiosis research: a review. Poultry Science, 93: 501-511. DOI: https://www.doi.org/10.3382/ps.2013-03634

Chapman HD, and Shirley MW (1989). Sensitivity of field isolates of Eimeria species to monensin and lasalocid in the chicken. Research in Veterinary Science, 46: 114-117. DOI: https://www.doi.org/10.1016/s0034-5288(18)31129-9

Chapman HD, Barta JR, Blake D, Gruber A, Jenkins M, Smith NC, Suo X, and Tomley FM (2013). A selective review of advances in coccidiosis research. Advances in Parasitology, 83: 93-171. DOI: https://www.doi.org/10.1016/b978-0-12-407705-8.00002-1

Chapman HD, Cherry TE, Danforth HD, Richards G, Shirley MW, and Williams RB (2002). Sustainable coccidiosis control in poultry production: the role of live vaccines. International Journal of Parasitology, 32: 617-629. https://www.doi.org/10.1016/s0020-7519(01)00362-9

Gharekhani J, Sadeghi-Dehkordi Z, and Bahrami M (2014). Prevalence of coccidiosis in broiler chicken farms in Western Iran. Journal of Veterinary Medicine, Article ID: 980604. DOI: https://www.doi.org/10.1155/2014/980604

Chen CY, Chuang LT, Chiang YC, Lin CL, Lien YY, and Tsen HY (2016). Use of a probiotic to ameliorate the growth rate and the inflammation of broiler chickens caused by Eimeria tenella infection. Journal of Animal Research and Nutrition, 1(2): 1-7. Available at: https://animalnutrition.imedpub.com/use-of-aprobiotic-to-ameliorate-the-growth-rate-and-the-inflammation-ofbroiler-chicke

Chen HL, Zhao XY, Zhao GX, Huang HB, Li HR, Shi CW, Yang WT, Jiang YL, Wang JZ, Ye LP et al. (2020). Dissection of the caecal microbial community in chickens after Eimeria tenella infection. Parasites and Vectors, 13: 56. DOI: https://www.doi.org/10.1186/s13071-020-3897-6

Chodová D, Tůmová E, Sládková K, Langrová I, Jankovská I, Vadlejch J, Čadková Z, and Krejčířová R (2018). Effects of subclinical Eimeria tenella infection on Pectoralis major muscle in broiler chickens. Italian Journal of Animal Science, 17(1): 18-21. DOI: https://www.doi.org/10.1080/1828051X.2017.1351899

Chroustova E, and Pinka K (1987). The efficacy of disinfectants on the oocysts of Eimeria tenella. Acta Veterineria BRNO, 56: 141-149. DOI: https://www.doi.org/10.2754/avb198756010141

Coufal CD, Chavez C, Niemeyer PR, and Carey JB (2006). Effects of top-dressing recycled broiler litter on litter production, litter characteristics, and nitrogen mass balance. Poultry Science, 85: 392-397. DOI: https://www.doi.org/10.1093/ps/85.3.392

Dalloul RA, and Lillehoj E (2006). Poultry coccidiosis: Recent advancements in control measures and vaccine development. Expert Review of Vaccines, 5: 143-163. DOI: https://www.doi.org/10.1586/14760584.5.1.143

Dalloul RA, Lillehoj HS, Tamim NM, Shellem TA, and Doerr JA (2005). Induction of local protective immunity to Eimeria acervulina by a Lactobacillus-based probiotic. Comparative Immunology, Microbiology and Infectious Diseases, 28: 351-361. DOI: https://www.doi.org/10.1016/j.cimid.2005.09.001

Dalloul RA, Lillehoj HS, Lee JS, Lee SH, and Chung KS (2006). Immunopotentiating effect of a Fomitella fraxinea derived lectin on chicken immunity and resistance to coccidiosis. Poultry Science, 85(3): 446-451. DOI: https://www.doi.org/10.1093/ps/85.3.446

Daugschies A, Bo"se R, Marx J, Teich K, and Freidhoff KT (2002). Development and application of a standardized assay for chemical disinfection of coccidia oocysts. Veterinary Parasitology, 103: 299308. DOI: https:/www./doi.org/10.1016/s0304-4017(01)00581-7

Delaplane JF, Batchelder RM, and Higgins TC (1947). Sulfaquinoxaline in the prevention of Eimeria tenella infections in chickens. North American Veterinarian, 28: 19-24. Available at: https://pubmed.ncbi.nlm.nih.gov/20290855/

De Pablos LM, Dos Santos MFB, Montero E, Garcia Granados A, Parra A, and Osuna A (2010). Anticoccidial activity of maslinic acid against infection with Eimeria tenella in chickens. Parasitology $\begin{array}{lll}\text { Research, } & \text { 107(3): } & \text { 601-604. }\end{array}$ https://www.doi.org/10.1007/s00436-010-1901-3

Dersjant-Li Y, Gibbs K, Awati A, and Klasing KC (2016). The effects of enzymes and direct fed microbial combination on performance and immune response of broilers under a coccidia challenge. Journal of 
Applied Animal and Nutrition, 4: e6. DOI: https://www.doi.org/10.1017/jan.2016.2

Dibner JJ, and Richards JD (2005). Antibiotic growth promoters in Agriculture: History and mode of action. Poultry Science, 83: 634643. DOI: https:/www./doi.org/10.1093/ps/84.4.634

Ding X, Lillehoj HS, Dalloul RA, Min W, Sato T, Yasuda A, and Lillehoj EP (2005). In ovo vaccination with the Eimeria tenella EtMIC2 gene induces protective immunity against coccidiosis. Vaccine, 23(28): $3733-3740 . \quad$ DOI: https://www.doi.org/10.1016/j.vaccine.2005.01.144

Dougherty HW (1974). Inhibition of mitochondrial energy transduction of carbanilides. Federation Proceedings, 33: 1657. Available at: https://www.tandfonline.com/doi/pdf/10.1080/03079459708419208

Dowling L (1992). Ionophore toxicity in chickens: A review of pathology and diagnosis. Avian Pathology, 21: 355-368. DOI: https://www.doi.org/10.1080/03079459208418854

Elmusharaf MA, Bautista V, Nollet L, and Beynen AC (2006). Effect of a mannaoligosaccharide preparation on Eimeria tenella infection in broiler chickens. International Journal of Poultry Science, 5: 583588. DOI: https://www.doi.org/10.3923/IJPS.2006.583.588

Elmusharaf MA, Peek HW, Nollet L, and Beynen AC (2007). The effect of and in-feed mannaoligosaccharide preparation (MOS) on a coccidiosis infection in broilers. Animal Feed and Science Technology, 134: 347-354. https://www.doi.org/10.1016/j.anifeedsci.2006.11.022

Erdoğmus SZ, Gülmez N, Findik A, Sah H, and Gülmez M (2019). Efficacy of probiotics on health status and growth performance of Eimeria tenella infected broiler chickens. Kafkas Universitesi Veteriner Fakultesi Dergisi, 25(3): 311-320. Available at: http://www.vetdergikafkas.org/pdf.php?\&id...

Etuk E, Okoli I, and Uko M. (2004). Prevalence and management issues associated with poultry coccidiosis in Abak agricultural zone of Akwa Ibom state, Nigeria. International Journal of Poultry Science, 3(2):135-139. Available https://citeseerx.ist.psu.edu/viewdoc/download?doi=10.1.1544.617 \&rep=rep1\&type=pdf

European Feed Manufacturers Guide (FEFAC) (2007). IFAH-Europe report to the European Commission on the future of Coccidiostats and Histomonostats. Final tripartite, 16 July 2007. Available at: https://www.european-poultry-science.com/Poultry-coccidiosisprevention-and-controlapproaches,QU1EPTQyMTg3ODEmTUIEPTE2MTAxNA.html

Felici M, Tugnoli B, Ghiselli F, Massi P, Tosi G, Fiorentini L, Piva A, and Grilli E (2020). In vitro anticoccidial activity of thymol, carvacrol, and saponins. Poultry Science, 99(11): 5350-5355. DOI: https://www.doi.org/10.1016/j.psj.2020.07.035

Finger A, and Michael A (2005). Maternal protection against Eimeria challenge of CoxAbic vaccinated chickens. In: Proceedings of the IX International Coccidiosis Conference, September 19-23, Foz do Iguassu, Brazil, p. 146.

Ford AM, Fagerberg DJ, Quarles CL, George BA, and McKinley GA (1981). Influence of salinomycin on incidence, shedding, and antimicrobial resistance of Salmonella typhimurium in experimentally infected broiler chicks. Poultry Science, 60: 24422453. DOI: https://www.doi.org/10.3382/ps.0602441

Gadde U, Kim WH, Oh ST, and Lillehoj HS (2017). Alternatives to antibiotics for maximizing growth performance and feed efficiency in poultry: A review. Animal Health Research Review, 18: 26-45. DOI: https://www.doi.org/10.1017/s1466252316000207

Gaucher ML, Quessy S, Letellier A, Arsenault J, and Boulianne M (2015). Impact of a drug-free program on broiler chicken growth performances, gut health, Clostridium perfringens and Campylobacter jejuni occurrences at the farm level. Poultry Science, $\quad 94:$ 1791-1801. DOI: https://www.doi.org/10.3382/ps/pev142

George BA, Ford AM, Fagerberg DJ, and Quarles CL (1982). Influence of salinomycin on antimicrobial resistance of coliforms and streptococci from broiler chickens. Poultry Science, 61: 1842-1852. DOI: https://www.doi.org/10.3382/ps.0611842

Giannenas I, Bonos E, Skoufos I, Tzora A, Stylianaki I, Lazari D, Tsinas A, Christaki E, and Florou-Paneri P (2018). Effect of herbal feed additives on performance parameters, intestinal microbiota, intestinal morphology and meat lipid oxidation of broiler chicken. British Poultry Science, 59: 545-553. DOI: https://www.doi.org/10.1080/00071668.2018.1483577

Gilbert JM, Bhanushali JK, and McDougald LR (1988). An enzymelinked immunosorbent assay for coccidiosis in chickens: correlation of antibody levels with prior exposure to coccidia in the laboratory and in the field. Avian Diseases, 32: 688-694. DOI: https://www.doi.org/10.2307/1590986

Godwin RM, and Morgan JAT (2015). A molecular survey of Eimeria in chickens across Australia. Veterinary Parasitology, 214: 16-21. DOI: https://www.doi.org/10.1016/j.vetpar.2015.09.030

Gordillo Jaramillo FX, Kim DH, Lee SH, Kwon S, Jha R, and Lee K (2021). Role of oregano and Citrus species-based essential oil preparation for the control of coccidiosis in broiler chickens. Journal of Animal Science and Biotechnology, 12: 47. DOI: https://www.doi.org/10.1186/s40104-021-00569-Z

Gu X, Zhang J, Li J, Wang Z, Feng J, Li J, Pan K, Ni X, Zeng D, Jing B et al. (2019). Effects of Bacillus cereus PAS38 on immune-related differentially expressed genes of spleen in broilers. Probiotics and Antimicrobial Proteins, 12(2): 425-438. DOI: https://www.doi.org/10.1007/s12602-019-09567-0

Gumara es Jr JS, Bogado ALG, da Cunha TCB, and Garcia JL (2007). In vitro evaluation of the disinfection efficacy on Eimeria tenella unsporulated oocysts isolated from broilers. Brazilian Journal of Veterinary Parasitology, 16: 67-71. PMID: 17706006. Available at: https://pubmed.ncbi.nlm.nih.gov/17706006/

Guo FC, Kwakkel RP, Williams BA, Suo X, Li WK, and Verstegen MW (2005). Coccidiosis immunization: Effects of mushroom and herb polysaccharides on immune responses of chickens with Eimeria tenella. Avian Diseases, 4: 70-73. DOI: https://www.doi.org/10.1637/7227-062504r1

Habibi H, Firouzi S, Nili H, Razavi M, Asadi SL, and Daneshi S (2016). Anticoccidial effects of herbal extracts on Eimeria tenella infection in broiler chickens: In vitro and in vivo study. Journal of Parasitic Diseases, 40(2): 401-407. DOI: https://www.dx.doi.org/10.1007\%2Fs12639-014-0517-4

Hackstein JHP, Mackenstedt U, Mehlhorn H, Meijerink JPP, Schubert H, and Leunissen JAM (1995). Parasitic apicomplexans harbor a chlorophyll a-D1 complex, the potential target for therapeutic triazines. Parasitology Research, 81: 207-216. DOI: https://www.doi.org/10.1007/BF00937111

Hafez MH (2008). Poultry coccidiosis: Prevention and control approaches. Arch. Geflügelk, 72(1): 2-7. Available at: https://www.european-poultry-science.com/Poultry-coccidiosisprevention-and-controlapproaches,QUIEPTQyMTg3ODEmTUIEPTE2MTAxNA.html

Hammond D (1973). Life cycles and development of coccidian. The Coccidia, pp. 45-79. Available at: https://link.springer.com/chapter/10.1007/978-94-015-6895-1_31

Hamzic E, Bed'Hom B, Juin H, Hawken R, Abrahamsen MS, Elsen JM, Servin B, Pinard-van der Laan MH, and Demeure O (2015). Largescale investigation of the parameters in response to Eimeria maxima challenge in broilers. Journal of Animal Science, 93(4): 1830-1840. DOI: https://www.doi.org/10.2527/jas.2014-8592

Harder A, and Haberkorn A (1989). Possible mode of action of toltrazuril: Studies on two Eimeria species and mammalian and Ascaris suum enzymes. Parasitology Research, 76: 8-12. DOI: https://www.doi.org/10.1007/bf00931064

Harfoush MA, Hegazy AM, Soliman AH, and Amer S (2010). Drug resistance evaluation of some commonly used anticoccidial drugs in broiler chickens. Journal of the Egyptian Society of Parasitology, 40(2): 337-348. Available at: https://pubmed.ncbi.nlm.nih.gov/21246941/ 
Hassan SM, El-Gayar AK, Cadwell DJ, Bailey CA, and Cartwright AL (2008). Guar meal ameliorates Eimeria tenella infection in broiler chicks. Veterinary Parasitology, 157: 133-138. DOI: https://www.doi.org/10.1016/j.vetpar.2008.07.005

Helmbolt CF, and Bryant ES (1971). The pathology of necrotic enteritis in domestic fowl. Avian Diseases, 15: 775-780. DOI: https://www.doi.org/10.2307/1588866

Hinsu AT, Thakkar JR, Koringa PG, Vrba V, Jakhesara SJ, Psifidi A, Guitian J, Tomley FM, Rank DN, Raman M et al. (2018). Illumina next generation sequencing for the analysis of Eimeria populations in commercial broilers and indigenous chickens. Frontiers $\begin{array}{llll}\text { in Veterinary } & \text { Science, } & 5: & 176 .\end{array}$ https://www.doi.org/10.3389/fvets.2018.00176

Hussein SHM, Mekawy S, Ayoub MA, Gehan NA, and Rania AA (2021). Comparative biochemical and pathological studies between toltrazuril and garlic supplementation in chickens experimentally infected with coccidiosis. Egyptian Journal of Animal Health, 1(1): 65-80. DOI: https://www.dx.doi.org/10.21608/ejah.2021.134362

Idris M, Abbas RZ, Masood S, Rehman T, Farooq U, Babar W, Hussain R, Raza A, and Riaz U (2017). The potential of antioxidant rich essential oils against avian coccidiosis. Worlds Poultry Science Journal, $\quad 73$ : 89-104. https://www.doi.org/10.1017/S0043933916000787

Jadhav BN, Nikam SV, Bhamre SN, and Jaid EL (2011). Study of Eimeria necatrix in broiler chicken from Aurangabad District of Maharashtra state India. The International Multidisciplinary Research Journal, 1(11): 11-12. Available at: https://updatepublishing.com/journal/index.php/imrj/article/view/15 22

James S (1980). Thiamine uptake in isolated schizonts of Eimeria tenella and the inhibitory effects of amprolium. Parasitology, 80: 313-322. DOI: https://www.doi.org/10.1017/S0031182000000779

Jarujareet W, Shigenoki Y, Taira K, and Ooi HK (2018). Eimeria tenella oocyst excretion and riboflavin supplement in infected chicken. Journal of Veterinary Medical Science, 80(9): 1392-1394. DOI: https://www.doi.org/10.1292/jvms.18-0219

Jeffers TK (1974). Eimeria acervulina and E. maxima: Incidence and anticoccidial drug resistance of isolants in major broiler-producing areas. Avian Diseases, 18: 331-342. DOI: https://www.doi.org/10.2307/1589101

Jenkins MC, Parker C, O'Brien C, Persyn J, Barlow D, Miska K, and Fetterer R (2013). Protecting chickens against coccidiosis in floor pens by administering Eimeria oocysts using gel beads or spray vaccination. Avian Diseases, 57(3): 622-626. DOI: https://www.doi.org/10.1637/10516-022213-reg.1

Johnson J, and Reid WM (1970). Anticoccidial drugs: lesion scoring techniques in battery and floor-pen experiments with chickens. Experimental Parasitology, 28: 30-36. DOI: https://www.doi.org/10.1016/0014-4894(70)90063-9

Jiao J, Yang Y, Liu M, Li J, Cui Y, Yin S, and Tao J (2018). Artemisinin and Artemisia аппиа leaves alleviate Eimeria tenella infection by facilitating apoptosis of host cells and suppressing inflammatory $\begin{array}{llll}\text { response. } & \text { Veterinary } & \text { Parasitology, 254: } 177 .\end{array}$ DOI: https://www.doi.org/10.1016/j.vetpar.2018.03.017

Jitviriyanon S, Phanthong $\mathrm{P}$, Lomarat $\mathrm{P}$, Bunyapraphatsara $\mathrm{N}$, Porntrakulpipat S, and Paraksa N (2016). In vitro study of anticoccidial activity of essential oils from indigenous plants against Eimeria tenella. Veterinary Parasitology, 228: 96-102. DOI: https://www.doi.org/10.1016/j.vetpar.2016.08.020

Kaleem QM, Akhtar M, Awais MM, Saleem M, Zafar M, Iqbal Z, Muhammad F, and Anwar MI (2014). Studies on Emblica officinalis derived tannins for their immunostimulatory and protective activities against coccidiosis in industrial broiler chickens. The Scientific World Journal, Article ID 378473. DOI: https://www.doi.org/10.1155/2014/378473

Khan M, Anjum AA, Nawaz M, Awan AR, and Ali MA (2019). Effect of newly characterized probiotic Lactobacilli on weight gain, immunomodulation and gut microbiota of Campylobacter jejuni challenged broiler chicken. Pakistan Veterinary Journal, 39: 473478. DOI: https://www.doi.org/10.29261/pakvetj/2019.051

Khan W, Das SN, Mahmoud AH, Rafique N, Anwar K, Khan BT, Ullah I, Khan M, Gul S, Gul R et al. (2021). Evaluation of sulfadimidine, amprolium and triquen to treat coccidiosis in wild pigeons. Brazilian Journal of Biology, 12(82): e238673. DOI: https://www.doi.org/10.1590/1519-6984.238673

Klasing KC, Adler KL, Remus JC, and Calvert CC (2002). Dietary betaine increases intraepithelial lymphocytes in the duodenum of coccidial-infected chicks and increases functional properties of phagocytes. Journal of Nutrition, 132: 2274-2282. DOI: https://www.doi.org/10.1093/jn/132.8.2274

Kogut MH (2019). The effect of microbiome modulation on the intestinal health of poultry. Animal Feed Science and Technology, 250: 3240. DOI: https://www.doi.org/10.1016/j.anifeedsci.2018.10.008

Lal K, Bromley E, Oakes R, Prieto JH, Sanderson SJ, Kurian D, Hunt L, Yates JR, Wastling JM, Sinden RE et al. (2009). Proteomic comparison of four Eimeria tenella life-cycle stages: unsporulated oocyst, sporulated oocyst, sporozoite and second-generation merozoite. Proteomics, 9(19): 4566-4576. DOI: https://www.dx.doi.org/10.1002\%2Fpmic.200900305

Lee SH, Lillehoj HS, Jang SI, and Lee KW (2011). Cinnamaldehyde enhances in vitro parameters of immunity and reduces in vivo infection against avian coccidiosis. British Journal of Nutrition, 106: 862-869 https://www.doi.org/10.1017/s0007114511001073

Lee SH, Lillehoj HS, Dalloul RA, Park DW, Hong YH, and Lin JJ (2007). Influence of Pediococcus-based probiotic on coccidiosis in broiler chickens. Poultry Science, 86: 63-66. DOI: https://www.doi.org/10.1093/ps/86.1.63

Lee SH, Lillehoj HS, Lillehoj EP, Cho SM, Park DW, Hong YH, Chun HK, and Park HJ (2008). Immunomodulatory properties of dietary plum on coccidiosis. Comparative Immunology, Microbiology and Infectious Diseases, 31(5): 389-402. DOI https://www.doi.org/10.1016/j.cimid.2007.06.005

Lee SH, Lillehoj HS, Jang SI, Hong YH, Min W, Lillehoj EP, Yancey RJ, and Dominowski P (2010). Embryo vaccination of chickens using a novel adjuvant formulation stimulates protective immunity against Eimeria maxima infection. Vaccine, 28(49): 7774-7778. DOI: https://www.dx.doi.org/10.1016\%2Fj.vaccine.2010.09.051

Lee JW, Kim DH, Kim YB, Jeong SB, Oh ST, Cho SY, and Lee KW (2020). Dietary encapsulated essential oils improve production performance of coccidiosis-vaccine-challenged broiler chickens. Animals, $10(3): \quad 481 . \quad$ DOI: https://www.dx.doi.org/10.3390\%2Fani10030481

Leung H, Yitbarek A, Snyder R, Patterson R, Barta JR, Karrow N, and Kiarie E (2018). Responses of broiler chickens to Eimeria challenge when fed a nucleotide-rich yeast extract. Poultry Science, 98(4): 1622-1633. DOI: https://www.doi.org/10.3382/ps/pey533

Li Y, and Bu S (2014). A simple and sensitive UHPLC-MS/ MS method for the determination of sulfachloropyrazine sodium in chicken plasma and application in a comparative pharmacokinetic study. Analytical Methods, 6(18): 7312-7317. DOI: http://www.doi.org/10.1039/c4ay00963k

Lillehoj HS, and Ruff MD (1987). Comparison of disease susceptibility and subclass specific antibody response in SC and FP chickens experimentally inoculated with Eimeria tenella, E. acervulina, or $E$ maxima. Avian Diseases, 31: 112-119. DOI: https://www.doi.org/10.2307/1590782

Lillehoj HS, and Trout JM (1996). Avian gut-associated lymphoid tissues and intestinal immune responses to Eimeria parasites. Clinical Microbiology Review, 9: 349-360. DOI: https://www.doi.org/10.1128/cmr.9.3.349

Lillehoj HS, Ding X, Dalloul RA, Sato T, Yasuda A, and Lillehoj EP (2005). Embryo vaccination against Eimeria tenella and E. acervulina infections using recombinant proteins and cytokine adjuvants. Journal of Parasitology, 91(3): 666-673. DOI: https://www.doi.org/10.1645/ge-3476 
Long PL, Johnson J, McKenzie ME, Perry E, Crane MS, and Murray PK (1986). Immunization of young broiler chickens with low level infections of Eimeria tenella, E. acervulina, or E. maxima. Avian Pathology, 15: 271-278. DOI: https://www.doi.org/10.1080/03079458608436287

Majed A, Naila C, Rifat U, and Gul S (2019). Anticoccidial effect of garlic (Allium Sativium) and ginger (Zingiber officinale) against experimentally induced coccidiosis in broiler chickens. Journal of Applied Animal Research, 47(1): 79-84. DOI: https://www.doi.org/10.1080/09712119.2019.1573731

Martel A, Devriese LA, Cauwerts K, De Gussem K, Decostere A, and Haesebrouck F (2004). Susceptibility of Clostridium perfringens strains from broilers chickens to antibiotics and anticoccidials. Avian Pathology, 33: 3-7. https://www.doi.org/10.1080/0307945031000163291

Mathis GF (1999). Anticoccidial sensitivity of recent field isolates of chicken coccidia. Poultry Science, 78: 116. Available at: https://www.jstor.org/stable/27565676

Mathis GF, Newman LJ, Fitz-Coy S, Lumpkins B, Charette R, and Fuller L (2017). Comparison of breeder/layer coccidiosis vaccines: Part 1precocity and pathogenicity. Journal of Applied Poultry Research, 27(1): 33-37. DOI: https://www.doi.org/10.3382/japr/pfx037

McDonald V, and Ballingall S (1983). Further investigation of the pathogenicity, immunogenicity and stability of precocious Eimeria acervulina. Parasitology, 86: 361-369. DOI: https://www.doi.org/10.1017/s0031182000050551

McDonald V, Shirley M, and Millard B (1986). A comparative study of two lines of Eimeria tenella attenuated either by selection for precocious development in the chicken or by growth in chicken embryos. Avian Pathology, 15: 323-335. DOI: https://www.doi.org/10.1080/03079458608436296

Mcdougald LR (2003). Coccidiosis. In: Disease of Poultry (11 $1^{\text {th }}$ eds) Saif YM, Barnes HJ, Glisson JR, Fadly AM, Mcdougald LR, and Swayne DE., Iowa State Press, Ames, Iowa, USA. pp. 974-991. Available at: https://www.amazon.com/Diseases-Poultry-Y-MSaif/dp/081380423X

Mcdougald LR, and $\mathrm{Hu} \mathrm{J}$ (2001). Blackhead disease (Histomonas meleagridis) aggravated in broiler chickens by concurrent infection with cecal coccidiosis (Eimeria tenella). Avian Diseases, 45: 307 312. DOI: https://www.doi.org/10.2307/1592969

Mcdougald LR, Karlsson T, and Reid WM (1979). Interaction of infectious bursal disease and coccidiosis in layer replacement chickens. Avian Diseases, 23: 999-1005. DOI: https://www.doi.org/10.2307/1589616

McManus EC, Campbell WC, and Cuckler AC (1968). Development of resistance to quinoline coccidiostats under field and laboratory conditions. Journal of Parasitology, 54: 1190-1193. DOI: https://www.doi.org/10.2307/3276989

Milbradt EL, Mendes AA, Ferreira JG, Almeida Paz I, Martins MB, Sanfelice C, Fernandes BC, and Okamoto AS (2014). Use of live oocyst vaccine in the control of turkey coccidiosis: Effect on performance and intestinal morphology. Journal of Applied Poultry Research, 23: 204-211. DOI: https://www.doi.org/10.3382/japr.2013-00877

Mohammadi Gheisar M, and Kim IH (2017). Phytobiotics in poultry and swine nutrition - a review. Italian Journal of Animal Science, 17(1): 92-99. DOI: https://www.doi.org/10.1080/1828051X.2017.1350120

Mohammed BR, and Sunday OS (2015). An overview of the prevalence of avian coccidiosis in poultry production and its economic importance in Nigeria. Veterinary Research, 3(3): 35-45. Available at: https://www.scinapse.io/papers/2550574668

Molan AL, and Faraj AM (2015). Effect of selenium-rich green tea extract on the course of sporulation of Eimeria oocysts. Journal of Dental and Medical Sciences, 14(4): 68-74. Available at: https://www.iosrjournals.org/iosr-jdms/papers/Vol14issue4/Version-3/Q014436874.pdf
Molan AL, Liu Z, and De S (2009). Effect of pine bark (Pinus radiata) extracts on sporulation of coccidian oocysts. Folia Parasitologica, 56(1): 1-5. DOI: https://www.doi.org/10.14411/FP.2009.001

Morris GM, Woods WG, Richards DG, and Gasser RB (2007). Investigating a persistent coccidiosis problem on a commercial broiler-breeder farm utilising PCR-coupled capillary electrophoresis. Parasitology Research, 101(3): 583-589. DOI: https://www.doi.org/10.1007/s00436-007-0516-9

Mottet A, and Tempio G (2017). Global poultry production: current state and future outlook and challenges. World's Poultry Science $\begin{array}{llll}\text { Journal, } & 73(2): & 245-256 . & \text { DOI: }\end{array}$ https://www.doi.org/10.1017/S0043933917000071

Musa IW, Sa'idu L, Jatau JT, Adamu J, Otu MO, and Abdu PA (2010). Outbreak of coccidiosis in 5-day old commercial breeder flock In Zaria, Nigeria. International Journal of Poultry Science, 9(12): $1112-1115$ https://www.dx.doi.org/10.3923/ijps.2010.1112.1115

Nghonjuyi NW, Tiambo CK, Kimbi HK, Manka'a CN, Juliano RS, and Lisita F (2015). Efficacy of ethanolic extract of Carica papaya leaves as a substitute of sulphanomide for the control of coccidiosis in KABIR chickens in Cameroon. Journal of Animal Health and Production, $3(1)$ : 21-27. http://www.dx.doi.org/10.14737/journal.jahp/2015/3.1.21.27

Noack S, Chapman HD, and Selzer PM (2019). Anticoccidial drugs of the livestock industry. Journal of Protozoology Research, 118: 2009-2026. DOI: https://www.doi.org/10.1007/s00436-019-06343$\underline{5}$

Nopvichai C, Charoenwongpaiboon T, Luengluepunya N, Ito K, Muanprasat C, and Pichyangkura R (2019). Production and purification of mannan oligosaccharide with epithelial tight junction enhancing activity. Peer Journal, 7: e7206. 56. DOI: https://www.dx.doi.org/10.7717\%2Fpeerj.7206

Nweze NE, and Obiwulu IS (2009). Anticoccidial effects of Ageratum conyzoides. Journal of Ethnopharmacology, 122(1): 6-9. DOI: https://www.doi.org/10.1016/j.jep.2008.11.014

Ocejo M, Oporto B, and Hurtado A (2019). 16S rRNA amplicon sequencing characterization of caecal microbiome composition of broilers and free-range slow-growing chickens throughout their productive lifespan. Scientific Reports, 9: 1-14. DOI: https://www.doi.org/10.1038/s41598-019-39323-x

O'Reilly EL, Bailey RA, and Eckersall PD (2018). A comparative study of acute-phase protein concentrations in historical and modern broiler breeding lines. Poultry Science, 97(11): 3847-3853. DOI: https://www.doi.org/10.3382/ps/pey272

Peek HW, and Landman WJM (2011). Coccidiosis in poultry: Anticoccidial products, vaccines and other prevention strategies. Veterinary Quarterly, 31: 143-161. DOI: https://www.doi.org/10.1080/01652176.2011.605247

Pinard-van der Laan MH, Bed'Hom B, Coville JL, Pitel F, Feve K, Leroux S, Legros H, Thomas A, Gourichon D, and Repérant JM (2009). Microsatellite mapping of QTLs affecting resistance to coccidiosis (Eimeria tenella) in a FayoumixWhite Leghorn cross. BMC Genomics, 10(1): 31. DOI: https://www.doi.org/10.1186/1471-2164-10-31

Pop LM, Varga E, Coroian M, Nedisan ME, Mircean V, Dumitrache MO, Fazakas M, and Györke A (2019). Efficacy of a commercial herbal formula in chicken experimental coccidiosis. Parasites and Vectors, 12: 343. DOI: https://www.doi.org/10.1186/s13071-019$\underline{3595-4}$

Price KR, Guerin MT, Newman L, Hargis BM, and Barta JR (2013). Examination of a novel practical poultry management method to enhance the effect of live Eimeria vaccination for conventionally housed replacement layer pullets. International Journal of Poultry Science, 12: 175-184. DOI: https://www.dx.doi.org/10.3923/ijps.2013.175.184

Price KR, Van-Heerden FMK, and Barta JR (2015). Shedding of live Eimeria vaccine progeny is delayed in chicks with delayed access 
to feed after vaccination. Veterinary Parasitology, 208: 242-245. DOI: https:/www./doi.org/10.1016/j.vetpar.2015.01.009

Price KR, Hafeez MA, Bulfon J, and Barta JR (2016). Live Eimeria vaccination success in the face of artificial non-uniform vaccine administration in conventionally reared pullets. Avian Pathology, 45: 82-93.

DOI https://www.doi.org/10.1080/03079457.2015.1125442

Quiroz-Castan eda RE, and Danta'n-Gonza'lez E (2015). Control of avian coccidiosis: Future and present natural alternatives. BioMed Research International, Article ID: 430610. DOI: https://www.doi.org/10.1155/2015/430610

Ramos FA, Martinez AP, Montes ES, Gaytan CN, Cazarez ASH, Tovar JC, Sanchez JG, and Castillo JDCR (2017). Oregano oil use in broiler diet increases accumulation of carvacrol and thymol in breast meat. Acta Universitaria, 27: 34-39. DOI: https://www.doi.org/10.15174/au.2017.1074

Reid WM (1973). Anticoccidials: Differences in day of peak against Eimeria tenella. Paper presented at: Symposium Coccidia and Related Organisms. Proceedings of the Symposium Coccidia and related Organism; Guelph, Ontario, Canada, pp. 119-134.

Reid WM (1975). Progress in the control of coccidiosis with anticoccidials and planned immunization. American Journal of Veterinary Research, 36: 593-596. PMID: 1092227. Available at: https://pubmed.ncbi.nlm.nih.gov/1092227/

Reid AJ, Blake DP, Ansari HR, Billington K, Browne HP, Bryant J, Dunn M, Hung SS, Kawahara F, Miranda-

Saavedra D et al. (2014). Genomic analysis of the causative agents of coccidiosis in domestic chickens. Genome Research, 24(10): 16761685. DOI: https://www.dx.doi.org/10.1101\%2Fgr.168955.113

Ritzi MM, Abdelrahman W, Mohnl M, and Dalloul RA (2014). Effects of probiotics and application methods on performance and response of broiler chickens to an Eimeria challenge. Poultry Science, 93(11): 2772-2778. DOI: https://www.doi.org/10.3382/ps.2014$\underline{04207}$

Royan M (2019). A review on the lactic acid bacteria probiotic in the control of coccidiosis, campylobacteriosis, and salmonellosis in broiler chickens. Iranian Journal of Applied Animal Science, 9(1): 1-8. Available at: http://ijas.iaurasht.ac.ir/article_663517.html

Saeed M, Babazadeh D, Naveed M, Alagawany M, Abd El-Hack ME, Arain MA, Tiwari R, Sachan S, Karthik K, Dhama K et al. (2019). In ovo delivery of various biological supplements, vaccines and drugs in poultry: current knowledge. Journal of the Science of Food and Agriculture, 99(8): 3727-3739. DOI: https://www.doi.org/10.1002/jsfa.9593

Sharkey DL (1998). Evaluation of coccidiosis in the presence of a mold inhibitor. Dissertation Abstracts International, 39B: 2032. Available at: http://www.iaetsdjaras.org/gallery/2-jaras-april-1085.pdf

Sharman PA, Smith NC, Wallach MG, and Katrib M (2010). Chasing the golden egg: vaccination against poultry coccidiosis. Parasite Immunology, 32(8): $590-598 . \quad$ DOI: https://www.doi.org/10.1111/j.1365-3024.2010.01209.x

Shirley MW, and Bedrnik P (1997). Live attenuated vaccines against avian coccidiosis: success with precocious and egg-adapted lines of Eimeria. Parasitology Today, 13: 481-484. DOI: https://www.doi.org/10.1016/s0169-4758(97)01153-8

Shirley MW, McDonald V, and Bellatti MA (1986). Eimeria brunetti: Selection and characteristics of a precocious (and attenuated) line. Avian Pathology, 15: 705-717. DOI: https://www.doi.org/10.1080/03079458608436333

Shivaramaiah C, Barta JR, Hernandez-Velasco X, Téllez G, and Hargis BM (2014). Coccidiosis: Recent advancements in the immunobiology of Eimeria species, preventive measures, and the importance of vaccination as a control tool against these Apicomplexan parasites. Veterinary Medicine, 5(5): 23-34. DOI: https://www.doi.org/10.2147/vmrr.s57839

Sidiropoulou E, Skoufos I, Marugan-Hernandez V, Giannenas I, Bonos E, Aguiar-Martins K, Lazari D, Blake DP, and Tzora A (2020). In vitro anticoccidial study of oregano and garlic essential oils and effects on growth performance, fecal oocyst output, and intestinal microbiota in vivo. Frontiers in Veterinary Science, 7: 420. DOI: https://www.doi.org/10.3389/fvets.2020.00420

Skoufos I, Bonos E, Anastasiou I, Tsinas A, and Tzora A (2020). Effects of phytobiotics in healthy or disease challenged animals. In Feed Additives: Aromatic Plants and Herbs in Animal Nutrition and Health; Florou-Paneri, P., Christaki, E., Giannenas, I., Eds.; Academic Press: London, UK, pp. 311-337. Available at: https://www.sciencedirect.com/science/article/pii/B9780128147009 $\underline{000182}$

Snyder RP, Guerin MT, Hargis BM, Page G, and Barta JR (2021). Monitoring coccidia in commercial broiler chicken flocks in Ontario: comparing oocyst cycling patterns in flocks using anticoccidial medications or live vaccination. Poultry Science, 100(1): 110-118. DOI: https://www.doi.org/10.1016/j.psj.2020.09.072

Sokale A, Zhai W, Pote L, Williams C, and Peebles E (2016). Effects of coccidiosis vaccination administered by in ovo injection on the hatchability and hatching chick quality of broilers. Poultry Science, 96(3):541-547. DOI: https://www.doi.org/10.3382/ps/pew370

Sokale A, Zhai W, Pote L, Williams C, and Peebles E (2017). Effects of coccidiosis vaccination administered by in ovo injection on Ross 708 broiler performance through 14 days of post-hatch age. Poultry Science, 96(8): 2546-2551. DOI: https://www.doi.org/10.3382/ps/pex041

Song X, Gao Y, Xu L, Yan R, and Li X (2015a). Partial protection against four species of chicken coccidia induced by multivalent subunit vaccine. Veterinary Parasitology, 212(3): 80-85. DOI: https://www.doi.org/10.1016/j.vetpar.2015.08.026

Song X, Ren Z, Yan R, Xu L, and Li X (2015b). Induction of protective immunity against Eimeria tenella, Eimeria necatrix, Eimeria maxima and Eimeria acervulina infections using multivalent epitope DNA vaccines. Vaccine, 33(24): 2764-2770. DOI: https://www.doi.org/10.1016/j.vaccine.2015.04.052

Soutter F, Werling D, Tomley FM, and Blake DP (2020). Poultry coccidiosis: Design and interpretation of vaccine studies. Frontiers in Veterinary Science, 7: 101. DOI: https://www.doi.org/10.3389/fvets.2020.00101

Sugiharto S (2014). Role of nutraceuticals in gut health and growth performance of poultry. Journal of the Saudi Society of Agricultural Sciences, $15(2)$ : $99-11 . \quad$ DOI: https://www.doi.org/10.1016/j.jssas.2014.06.001

Sundar STB, Harikrishnan TJ, Latha BR, Chandra GS, and Senthil Kumar TMA (2016). Smart delivery of antiparasitic vaccines of veterinary importance - a review. International Journal of Science, Environment and Technology, 5:2426-243. Available at: https://www.ijset.net/journal/1176.pdf

Tamasaukas R, Ruiz H, Theis W, and De Basillio V (1997). Efficacy of a disinfectant composed by citric extracts in a floor-pen trail with broilers in Venezuela. Latin American Animal Production Archives, 5: 612-615. Available at: https://ojs.alpa.uy/index.php/ojs_files/article/view/385

Tauer SK, Holt JP, Underwood KR, Levesque CL, and Thaler RC (2019). Performance, histology, and meat quality of coccidiosischallenged broilers fed essential oils. Meat Muscle Biology, 3: 1321. DOI: https://www.doi.org/10.22175/mmb2018.07.0019

Thabet A, Zhang R, Alnassan A, Daugschies A, and Bangoura B (2017). Anticoccidial efficacy testing: In vitro Eimeria tenella assays as replacement for animal experiments. Veterinary Parasitology, 233: 86-96. DOI: https://www.doi.org/10.1016/j.vetpar.2016.12.005

Tsiouris V, Georgopoulou I, Batzios C, Pappaioannou N, Diakou A, Petridou E, Ducatelle R, and Fortomaris P (2013). The role of an attenuated anticoccidial vaccine on the intestinal ecosystem and on the pathogenesis of experimental necrotic enteritis in broiler chickens. Avian Pathology, 42: 163-170. DOI: https://www.doi.org/10.1080/03079457.2013.776161

Tsiouris V, Giannenas I, Bonos E, Papadopoulos E, Stylianaki I, Sidiropoulou E, Lazari D, Tzora A, Ganguly B, and Georgopoulou 
I (2021). Efficacy of a dietary polyherbal formula on the performance and gut health in broiler chicks after experimental infection with Eimeria spp. Pathogens, 10: 524. DOI: https://www.doi.org/10.3390/pathogens10050524

Verheyen A, Maes L, Coussement W, Vanparijs O, Lauwers F, Vlaminckx E, Borgers M, and Marsboom R (1988). In vivo action of the anticoccidial diclazuril (Clinacox) on the development stages of Eimeria tenella an ultrastructural evaluation. Journal of Parasitology, 74: 939-949. PMID: 3193333 Available at: https://pubmed.ncbi.nlm.nih.gov/3193333/

Verheyen A, Maes L, Coussement W, Vanparijs O, Lauwers F, and Marsboom R (1989). Ultrastructural evaluation of the effects of diclazuril on the endogenous stages of Eimeria maxima and E. brunetti in experimentally inoculated chickens. Parasitology Research, 75: 604-610. DOI: https:/www./doi.org/10.1007/bf00930956

Vermeulen AN, Schaap DC, and Schetters T (2001). Control of coccidiosis in chickens by vaccination. Veterinary Parasitology, 100: 13-20. DOI: https://www.doi.org/10.1016/s03044017(01)00479-4

Vrba V, Blake DP, and Poplstein M (2010). Quantitative real-time PCR assays for detection and quantification of all seven Eimeria species that infect the chicken. Veterinary Parasitology, 174:183-190. DOI: https://www.doi.org/10.1016/j.vetpar.2010.09.006

Wallach M, Smith NC, Petracca M, Miller CMD, Eckert J, and Braun R (1995). Eimeria maxima gametocyte antigen: potential use in a subunit maternal vaccine against coccidiosis in chickens. Vaccine, 13: 347-354. DOI:_https://www.doi.org/10.1016/0264410X\%2895\%2998255-9

Wang CC (1975). Studies of the mitchondria from Eimeria tenella and inhibition of the electron transport by quinolone coccidiostats. Biochimica et Biophysica Acta, 396: 210-219. DOI: https://www.doi.org/10.1016/0005-2728(75)90035-3

Wang ML, Suo X, Gu JH, Zhang WW, Fang Q, and Wang X (2008). Influence of grape seed proanthocyanidin extract in broiler chickens: effect on chicken coccidiosis and antioxidant status.

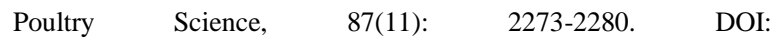
https://www.doi.org/10.3382/ps.2008-00077

Wang D, Zhou L, Li W, Zhou H, and Hou G (2018). Anticoccidial effects of areca nut (Areca catechu L.) extract on broiler chicks experimentally infected with Eimeria tenella. Experimental Parasitology, 184: 16-21. https://www.doi.org/10.1016/j.exppara.2017.11.002

Wang X, Farnell YZ, Kiess AS, Peebles ED, Wamsley KGS, and Zhai W (2019). Effects of Bacillus subtilis and coccidial vaccination on caecal microbial diversity and composition of Eimeria challenged male broilers. Poultry Science, 98(9): 3839-3849. DOI: https://www.doi.org/10.3382/ps/pez096

Watkins KL, Brooks MA, Jefers TK, Phelps PV, and Ricks CA (1995). The effect of in ovo oocyst or sporocyst inoculation on response to subsequent coccidial challenge. Poultry Science, 74(10): 15971602. DOI: https://www.doi.org/10.3382/ps.0741597

Williams RB (2002). Fifty years of anticoccidial vaccines for poultry (1952-2002). Avian Diseases, 46: 775-802. DOI: https://www.doi.org/10.1637/00052086(2002)046[0775:fyoavf]2.0. $\underline{\mathrm{co} ; 2}$

Williams RB, and Catchpole J (2000). A new protocol for a challenge test to assess the efficacy of live anticoccidial vaccines for chickens. Vaccine, 18: 1178-1185. DOI: https://www.doi.org/10.1016/s0264-410x(99)00387-4

Wong DT, Horng JS, and Wilkinson JR (1972). Robenidine, an inhibitor of phosphorylation. Biochemical and Biophysical Research Communications, $\quad 46:$ 621-627. DOI: https://www.doi.org/10.1016/s0006-291x(72)80185-2

Wu Y, Zhen W, Geng Y, Wang Z, and Guo Y (2019). Effects of dietary Enterococcus faecium NCIMB 11181 supplementation on growth performance and cellular and humoral immune responses in broiler chickens. Poultry Science, 98(1): 150-163. DOI: https://www.doi.org/10.3382/ps/pey368

Yadav S, and Jha R (2019). Strategies to modulate the intestinal microbiota and their effects on nutrient utilization, performance, and health of poultry. Journal of Animal Science and Biotechnology, 10: 2. DOI: https://www.doi.org/10.1186/s40104018-0310-9

Yang C, Kennes YM, Lepp D, Yin X, Wang Q, Yu H, Yang C, Gong J, and Diarra MS (2020). Effects of encapsulated cinnamaldehyde and citral on the performance and cecal microbiota of broilers vaccinated or not vaccinated against coccidiosis. Poultry Science, 99(2): 936-948. DOI: https://www.doi.org/10.1016/j.psj.2019.10.036

Yang WC, Yang CY, Liang YC, Yang CW, Li WQ, Chung CY, Yang MT, Kuo TF, Lin CF, Liang CL et al. (2019). Anticoccidial properties and mechanisms of an edible herb, Bidens pilosa, and its active compounds for coccidiosis. Scientific Reports, 9(1): 2896. DOI: https://www.doi.org/10.1038/s41598-019-39194-2

Yegani M, and Korver DR (2008). Factors affecting intestinal health in poultry. Poultry Science, 87(10): 2052-2063. DOI: https://www.doi.org/10.3382/ps.2008-00091

Yin G, Lin Q, Qiu J, Qin M, Tang X, Suo X, Huang Z, and Liu X (2015). Immunogenicity and protective efficacy of an Eimeria vaccine candidate based on Eimeria tenella immune mapped protein 1 and chicken CD40 ligand. Veterinary Parasitology, 210(1): 19-24. DOI: https://www.doi.org/10.1016/j.vetpar.2015.03.012

Zhai H, Liu H, Wang S, Wu J, and Kluenter AM (2018). Potential of essential oils for poultry and pigs. Animal Nutrition, 4: 179-186. DOI: https://www.doi.org/10.1016/j.aninu.2018.01.005

Zhai Q, Huang B, Dong H, Zhao Q, Zhu S, Liang S, Li S, Yang S, and Han H (2016). Molecular characterization and immune protection of a new conserved hypothetical protein of Eimeria tenella. PLoS One, 11(6): e0157678. https://www.doi.org/10.1371/journal.pone.0157678

Zhang DF, Sun BB, Yue YY, Zhou QJ, and Du AF (2012). Anticoccidial activity of traditional Chinese herbal Dichroa febrifuga Lour extract against Eimeria tenella infection in chickens. Parasitology Research, 111(6): 2229-2233. DOI: https://www.doi.org/10.1007/s00436-012-3071-y 